\title{
"LENDO O BARALHO": O OLHAR, AS IMPRESSÕES E AS RELAÇÕES DE UM GRUPO DE SENHORAS COM A REDE DE USUÁRIOS E VENDEDORES DE DROGAS EM UMA VILA DE PORTO ALEGRE.
}

\author{
Dênis Roberto da Silva Petuco \\ Cornelia Eckert (Orientação) \\ "Nunca fiz mais do que fumar a vida". \\ Álvaro de Campos
}

\section{Introdução}

Tudo começou porque eu queria pesquisar um grupo de usuários de crack do Morro da Cruz, do qual já venho tentando me aproximar em função de meu trabalho como Agente Redutor de Danos ${ }^{1}$ (Bastos; Mesquita \& Marques, 1998; Brasil, 2003; Piccolo, 2001, Gregis, 2002). Pensei que poderia unir as duas coisas - trabalho e academia - utilizando a segunda como desculpa para uma aproximação, tão importante ao primeiro.

Sendo este um trabalho para uma cadeira introdutória, e não sendo este o momento ideal para um projeto que envolva problemas de ordem ética (como o sigilo e a periculosidade, por exemplo), recebi a orientação para escolher um outro universo de pesquisa. Como não quisesse abrir mão do tema do consumo de drogas, pensei em utilizar uma espécie de "escudo protetor", a partir do qual eu poderia olhar para o problema de maneira diagonal ${ }^{2}$. Para tanto, a opção por grupos geográfica e socialmente próximos a uma rede de drogas pareceu-me interessante.

\footnotetext{
1 - O Agente Redutor de Danos é um profissional semelhante ao Agente Comunitário de Saúde, com a especificidade de atuar junto a usuários de drogas. O Programa de Redução de Danos está subordinado à Coordenação de Política Municipal de Controle em DST/Aids, ligada à Secretaria Municipal de Saúde de Porto Alegre. Isto ocorre porque, em sua origem, as ações de redução de danos limitavam-se quase que unicamente à troca de seringas, com vistas à prevenção da Aids entre usuários de drogas injetáveis. Hoje, esta atuação é muito mais ampla.

2 - Para maiores esclarecimentos sobre o método diagonal, ler o trecho intitulado "Referenciais Reflexivos".
} 
O objetivo inicial deste trabalho era pesquisar o olhar de dois grupos de senhoras da Vila São João - mais conhecida como Morro da Cruz - sobre a rede de drogas ilícitas da mesma região, compreendendo-se por rede de drogas todo o conjunto de sujeitos que usam, vendem, compram e distribuem drogas. Porém, da apresentação desta proposta no início do semestre até agora, algumas coisas mudaram.

A primeira mudança foi de sentido prático. Um dos grupos de senhoras que desejava pesquisar era constituído pelas famosas costureiras do Morro da Cruz, que produzem roupas a partir de refugos de materiais têxteis devidamente reciclados (quanto ao outro grupo, este será descrito mais detalhadamente no capítulo "Descrição do Universo de Pesquisa”, subitem "A Casa das Vós e as Caminheiras da Paz”). Logo em meu primeiro dia de campo, porém, descobri que a coordenadora da Grife Morro da Cruz havia acabado de sofrer um derrame, devendo ficar hospitalizada, e posteriormente em repouso, por algum tempo. Somente depois vim a perceber que a decisão de centralizar a pesquisa em apenas um grupo de senhoras - tomada inicialmente por motivos de força maior - acabou por colaborar imensamente para a viabilidade do trabalho.

As outras mudanças se deram a partir dos trabalhos de observação direta no campo, e principalmente durante as entrevistas individuais. Passou a ficar cada vez mais claro a total impossibilidade de restringir a pesquisa a uma análise do olhar destas senhoras sobre os usuários e vendedores de drogas da região. Restringir-se a isto seria como que ignorar a existência de todo um emaranhado de relações de troca que, em vários momentos, irá até mesmo dificultar a separação entre um e outro grupo. Por fim, um último item sobre o qual decidi me debruçar foi a formação de um tipo muito específico de mito, ligado à figura do "bom ladrão" ou mesmo do "herói bandido". Este tipo de mito foi recorrente nas conversas com o grupo, fazendo-me crer que se trata de um elemento importante na formação da identidade e do ethos $^{3}$ deste grupo, e, talvez, da comunidade como um todo.

A opção por trabalhar com um grupo de terceira idade previamente organizado, que utiliza como espaço de encontro semanal uma casa situada em um local-símbolo do "Mundo das Drogas" (Velho, 1994), em Porto Alegre (Fonseca, 2000), possui vantagens e desvantagens. As vantagens são praticamente óbvias: dentre elas, talvez a mais importante seja a proximidade social, afetiva e geográfica destas senhoras com os sujeitos que compõe

3 - Ethos é aqui compreendido na perspectiva de Clifford Geertz (Geertz, 1989). 
a rede de drogas naquela localidade, não apenas hoje, mas ao longo de décadas. Uma outra vantagem considerável é a organização pré-existente deste grupo, que facilita o trabalho do pesquisador. Por fim, mas não menos importante: o fato deste grupo ser coordenado por uma pessoa que, além de ser uma boa amiga, é uma profissional extremamente competente, tornou tudo muito mais fácil para este "projeto de pesquisador" que vos escreve.

No que tange às desvantagens, posso citar tão somente uma, de caráter absolutamente pessoal: a quase que total deficiência do autor no que diz respeito ao universo do idoso. Trabalhando com prevenção, recuperação e redução de danos junto à pessoas com problemas relacionados ao uso indevido de drogas, e pesquisando de maneira autodidata estes mesmo problemas, eu terminei, quase que naturalmente, me aproximando dos jovens adultos e adolescentes. Para superar minimamente esta deficiência, a ajuda da Mestra em Enfermagem Aline Iara de Souza, que desenvolveu seu mestrado a partir de suas experiências com idosos da Vila Pitinga, na Lomba do Pinheiro, foi fundamental.

A monografia que se apresenta está dividida em quatro capítulos. No primeiro, apresento uma contextualização do problema, abordando superficialmente o processo histórico e a situação atual das políticas para o idoso, e também das políticas de drogas no Brasil e no mundo. A superficialidade deve-se ao fato de que tais temas possuem uma tamanha complexidade, que uma contextualização que merecesse realmente este nome tomaria um maior número de páginas que o próprio trabalho em si.

O segundo capítulo, já apresentado previamente à avaliação da Professora Cornélia Eckert, traz uma descrição do universo de pesquisa, com um enfoque que contempla tanto o processo quanto à estrutura, ainda que de maneira superficial.

No terceiro, vamos finalmente olhar com mais cuidado para os diários de campo, e para o universo que surge a partir das entrevistas realizadas. Para facilitar a análise, subdividi este capítulo em quatro partes: “As Histórias”, “Os Olhares”, “As Relações” e "Os Mitos".

Por fim, um último capítulo, destinado ao exercício de síntese e contemplação dos resultados. Isto se for possível chamar de "resultados" a qualquer conceitualização ou teorização surgida de dados coletados e refletidos em tão curto espaço de tempo. Porém, como início de um projeto maior, talvez exista aqui algum valor. 
Para encerrar esta (talvez) pouco convencional abertura, valho-me da introdução do maravilhoso livro de Wagner Gonçalves da Silva, "O Antropólogo e sua Magia". Neste livro, fruto de um trabalho que desloca o antropólogo de "sujeito" para "objeto" da pesquisa antropológica, Wagner alerta para o fato de que uma obra nem sempre é escrita da maneira como o leitor a lê. Diz ele que:

\footnotetext{
Quem já escreveu uma etnografia sabe que a "introdução" geralmente é escrita depois da "conclusão", quando o projeto então é apresentado de forma quase linear, retirados os desvios de rotas, hipóteses que não se confirmaram, percalços do caminho, etc. (Silva, 2000)
}

Esta introdução não está sendo escrita ao fim dos trabalhos. Enquanto a escrevo, há ainda muito pela frente. Ainda preciso cruzar minhas experiências de campo com elementos das obras com as quais decidi dialogar. Preciso também encontrar ainda artigos ou livros sobre um último tema. Já concluí, porém, importantes etapas do trabalho, e tenho claras em minha mente as teorias nas quais pretendo embasar minhas suspeitas, e os conceitos e categorias que pretendo utilizar para definir determinadas interpretações. Escrevo, portanto, esta introdução, como estratégia de balanço do que já tenho e do ainda me falta, e a manterei intacta ao terminá-la, para que sirva de testemunho do pé em que se encontrava este trabalho no dia de hoje: quatro de junho de 2004.

\section{Referenciais Reflexivos}

Apesar da recente iniciação nas teorias da antropologia e da sociologia, considerei um exercício interessante tentar identificar onde estariam situados os referenciais reflexivos e a metodologia de campo que utilizei, tanto na coleta de dados, como na objetivação deste trabalho. Diferentemente dos "antropólogos de verdade", minhas escolhas seguiram uma lógica absolutamente casuística, partindo de minhas impressões a respeito do que deveria ser, enfim, um método de trabalho. A inspiração aconteceu naturalmente a partir de alguns referenciais pessoais que, apesar de não estarem necessariamente embasados em teorias propriamente reconhecíveis, foram ainda assim importantes para orientar meus passos durante este trabalho: respeito aos direitos humanos, transparência e amor à verdade. 
Uma preocupação que tive desde o início foi com o fato de que meu olhar sobre a realidade pesquisada seria sempre um olhar, e nada mais. A revelia deste, haverá sempre uma infinidade de possibilidades de outros olhares, de novas leituras. E, sendo assim, como fazer com que a partir deste meu olhar seja possível produzir um conhecimento relevante para outras pessoas? Como afirmar suspeitas de modo que o leitor possa reconhecê-las como tais, e a partir desta experiência de diálogo subjetivo, possa construir ele também as suas próprias suspeitas?

Há alguns anos, conheci alguma coisa da obra de Ludwig Wittgenstein. Apesar do hermetismo do autor, acredito que consegui captar o centro de sua perspectiva: se em Schopenhauer existe um profundo desencanto diante da descoberta de que os fenômenos carecem de significado intrínseco, em Wittgenstein, esta mesma premissa irá produzir um sentimento de liberdade sem precedentes. Não se trata de uma afirmação do laisez-faire, mas sim de um novo e ampliado campo de possibilidades.

Sendo assim, minha primeira definição metodológica consistiu-se em manter a mente atenta para os possíveis fechamentos dogmáticos em algumas questões, a partir de pressupostos absolutamente arbitrários. Em outras palavras: se eu interpreto determinados eventos de uma determinada maneira, isto não deve ser confundido com a afirmação de que tais fenômenos são de determinada maneira. Não posso, portanto, confundir a realidade com a leitura da realidade.

A utilização da palavra "interpretação" e a referência a Wittgenstein trazem diretamente um outro autor à cena: Clifford Geertz. Não pude deixar de empolgar-me com a exposição que a Professora Cornelia Eckert fez sobre as teorias deste autor. Não que isto tenha significado que a partir daquele momento eu tenha optado por uma abordagem interpretativa de minhas experiências de campo. Não é isto. Trata-se, isto sim, de identificar que o tipo de olhar e de reflexão que eu vinha construindo acerca da pesquisa de campo estavam, ainda que intuitivamente, próximos deste referencial teórico. A relativização, a consciência da inseparatividade entre sujeito e objeto, e, finalmente, a utilização de referenciais distantes das Ciências Sociais. Sobre este último ponto, carreguei dúvidas até aquela aula sobre Geertz; afinal, pode-se ou não utilizar referências da literatura, da música e do cinema? Afinal, quero comparar algumas de minhas suspeitas com personagens do cinema e da literatura, como Boca de Ouro, Lampião, João de Santo Cristo, e outros. 
Descobri, por fim, que isto é possível, e que tais práticas estão novamente alinhadas às concepções de Geertz.

Outro ponto que me chamou a atenção em Geertz foi seu conceito weberiano de cultura. Parece-me que aí está um pressuposto que consegue situar-se exatamente no limite entre a liberdade e o rigor acadêmico, ampliando em muito os horizontes do pesquisador. Desta definição de cultura, pincei uma citação que me agradou de maneira especial:

Acreditando, como Max Weber, que o homem é um animal amarrado em teias de significados que ele mesmo teceu, assumo a cultura como sendo essas teias e a sua análise; portanto, não como uma ciência experimental em busca de leis, mas como uma ciência interpretativa, à procura do significado. (Geertz, 1989)

Por fim, a utilização do dito "método diagonal", descrito e definido pela antropóloga Rita Amaral no livro de Wagner Gonçalves da Silva, também se demonstrou de fundamental importância. Este método, porém, está muito mais ligado ao campo do que ao processo de objetivação, o que me leva a suspeitar, diferentemente de concepções que vinha construindo até aqui, que as teorias não nos acompanham apenas nos momentos solitários em frente à tela do computador, mas mesmo no turbilhão do trabalho de campo. Afinal, reconhecer a inseparatividade entre sujeito e objeto, e a ausência de significado intrínseco aos fenômenos, no campo, pode significar a diferença entre receber uma determinada informação ou não.

\section{Contextualizando}

Este exercício de contextualização tem por objetivo trazer algumas informações importantes para que o texto que irá seguir-se encontre, junto ao leitor, um terreno minimamente preparado para a recepção das "sementes de dúvida" que serão ali depositadas. 
Outra dificuldade diz respeito à própria natureza do trabalho. Devido ao modo como realizei a pesquisa, surge a necessidade de que eu contextualize dois temas diferentes: o mundo da droga e o mundo da velhice.

Contextualizar estes temas de maneira satisfatória, ou como eu realmente gostaria, será absolutamente impossível. Afirmo isto em face de reconhecer que estes temas - drogas e envelhecimento - possuem interfaces em uma série de outros temas, como economia, política, cultura e medicina, só para ficarmos em alguns. Esbarramos, pois, nos limites impostos pela compreensão do mundo como um arranjo de sistemas complexos, como exposto na metáfora de Edgard Morin:

\footnotetext{
Consideramos uma tapeçaria contemporânea. Comporta fios de linho, de seda, de algodão, de lã, com cores variadas. Para conhecer esta tapeçaria, seria interessante conhecer as leis e os princípios respeitantes a cada um destes tipos de fios. No entanto, a soma dos conhecimentos sobre cada um destes tipos de fios que entram na tapeçaria é insuficiente, não apenas para conhecer esta realidade nova que é o tecido (quer dizer, as qualidades e as propriedades próprias desta textura), mas, além disso, é incapaz de nos ajudar a conhecer sua forma e configuração. (Morin, 1991)
}

O que segue será, pois, um exercício de contextualização limitado por aspectos temporais, e também pela incapacidade do autor em ir além do que será apresentado, pelo menos por hora. Porém, se a limitação temporal reduz o poder de fogo do pesquisador no que diz respeito à coleta e objetivação de dados relativos ao contexto estudado, por outro lado, apresenta uma boa oportunidade ao leitor para que este possa conhecer um pouco mais sobre o autor. Afinal, a simples escolha de um determinado aspecto do tema em detrimento de outros fala não apenas do objeto da pesquisa, mas também do sujeito.

Por fim, convém anunciar que, para tornar as coisas mais fáceis (para o autor, a bem da verdade), optou-se por separar o capítulo em dois tópicos: "O Mundo da Droga" e "O Mundo do Envelhecimento".

\subsection{O Mundo da Droga}

O ser humano sempre utilizou substâncias capazes de provocar mudanças no funcionamento do sistema nervoso central, e que, por conseqüência, alteram também seu 
comportamento e sua percepção da realidade. Os registros mais antigos do uso de drogas datam de cerca de cinco mil anos, na China, Egito e Suméria (Escohotado, 1995). Impossível também não citar a referência bíblica ao uso do vinho por parte de Noé, que teria se utilizado da bebida até chegar a ponto de ficar completamente desnudo diante de seus filhos, algo não muito comum até mesmo para os padrões contemporâneos de comportamento. Em Roma, no ano cem depois de Cristo, Galeno recomendava cuidados especiais para que o uso de álcool e ópio não produzisse ressaca (Pessoti, 1999). Nas sociedades primitivas ao redor do mundo, uma infinidade de substâncias alucinógenas foram e ainda são empregadas em cerimônias mais ou menos secretas. $\mathrm{Na}$ Índia, os hindus utilizam a maconha pelo menos uma vez por ano, e os Rastafaris jamaicanos consideram esta mesma substância como sendo um poderoso elo de ligação entre o homem e Deus, chamado por eles de Jah. Contemporaneamente temos os grupos que utilizam o Ayahuasca, também conhecido como Santo Daime (MacRae, 1994). Enfim, os exemplos do uso religioso e cultural de substâncias psicoativas são inúmeros.

Com o surgimento de uma cultura de consumo desenfreada, começam também a aparecer com mais força os problemas ligados ao uso abusivo e à dependência destas mesmas substâncias. A partir daí, em parte pela natureza consumista da sociedade moderna (Conte, 2004), em parte pelo desaparecimento do "escudo protetor" que o caráter espiritual e cultural presente no uso destas substâncias oferecia aos seus usuários (Zoja, 1992), começam a surgir mais e mais pessoas cuja capacidade de controle em sua relação com as drogas está muito abaixo do aceitável. Tal descontrole acarreta sérios problemas de ordem física, psíquica, emocional e social. Hoje, em pleno século vinte e um, não só não resolvemos este problema, como o vemos crescer e assumir novas cores a cada dia, apesar dos esforços dos governos e da sociedade civil.

Apesar de serem conhecidas e utilizadas ao longo de toda a história da humanidade, provavelmente nunca se falou tanto em problemas relacionados ao uso indevido de drogas. A própria terminologia gera discussões intermináveis, e definir um indivíduo como "usuário", "viciado" ou "dependente" fala muito mais do sujeito que define que do objeto definido. A psicologia, por exemplo, vai entender esta questão a partir do ponto de vista das diferentes escolas: para um lacaniano, os distúrbios decorrentes do uso de drogas podem ser fruto de um desequilíbrio nas relações entre corpo, self e objeto (Filho, 
1999); para um psicanalista freudiano, talvez a origem destes distúrbios esteja na falta de um ego integrado com o qual se possa enfrentar as adversidades (Kalina, 1999); para um psicólogo junguiano, a inexistência ou fragilidade dos ritos de passagem em nossa sociedade talvez contribua para uma supervalorização do uso de drogas por parte de nossa juventude (Zoja, 1992). Já no campo da medicina, onde o tema do uso indevido de drogas somente começou a ser desenvolvido com mais seriedade a partir do século XVIII (Berridge, 1994), também não há consensos, e encontramos desde médicos que recomendam o uso de maconha como auxiliar no tratamento de problemas decorrentes da Aids ${ }^{4}$, até outros que desconsideram a possibilidade de uso recreativo de substâncias ilícitas, diagnosticando todos os indivíduos que se utilizam destas substâncias como “dependentes químicos" ou "toxicômanos". No campo do Direito, há também uma multiplicidade de visões, que vão do modelo proibitivo e repressivo, que recomenda penas restritivas de liberdade ao usuário de drogas, até o outro extremo, onde encontramos os que defendem uma legalização ampla, geral e irrestrita. No caminho do meio, temos a vertente da descriminalização ${ }^{5}$, extremamente em voga na atualidade, passando ainda pela concepção de justiça terapêutica ${ }^{6}$.

Esta multiplicidade de visões acaba por transformar as diferentes instâncias, envolvidas de uma forma ou de outra com o mundo da droga, em um palco onde ocorrem as disputas políticas, num exemplo extremamente bem acabado dos processos descritos por Gramsci, quando este elaborou suas teorias com respeito à noção de "Estado Ampliado". Estas disputas tencionam a sociedade, que participa de maneira tímida e pouco efetiva destas discussões, e ainda menos, das eventuais decisões. Como que num arremedo de Ágora, estes diferentes palcos de disputa - academia, associações, conselhos e governos -

\footnotetext{
${ }^{4}$ - Alguns médicos recomendam o uso de maconha a pessoas doentes de Aids por sua capacidade de despertar o apetite, ou ainda por uma suposta capacidade de fazer com que os enjôos decorrentes da ingestão do "coquetel" diminuam. A respeito destas práticas, ainda não existem estudos conclusivos, mas sabe-se que estas vêm sendo adotadas legalmente em alguns países, e de maneira ilegal por alguns médicos, inclusive no Brasil.

5 - No momento em que escrevo este trecho, o congresso nacional discute a reformulação da Lei 6368, de 1976. O PL 8123, de autoria do Deputado Paulo Pimenta, vem sendo erroneamente anunciando como u m projeto de descriminalização do uso de drogas no Brasil. Nada mais equivocado: trata-se, quando muito, de um projeto de despenalização, pois prevê o fim da pena de prisão ao usuário de drogas, mantendo, porém, outros níveis de penalização.

6 - Para uma leitura mais critica da dita "Justiça Terapêutica", ver a entrevista do ex-secretário de segurança do Rio de Janeiro, Nilo Baptista, para a revista Caros Amigos de agosto de 2003 (MORETZSOHN, Sylvia, et alli. "Todo crime é político": Entrevista com Nilo Baptista. Caros Amigos. São Paulo: Ano VII, n.77, Ago. 2003. p. $28-33)$.
} 
tornam-se simulacros de representação, onde os atores representam papéis muitas vezes desconectados de uma eventual legitimidade democrática.

O resultado concreto de tudo isto? A indefinição como regime. Em meio a uma repressão ineficiente, justificada legalmente, porém cada vez mais questionada politicamente, o tráfico move-se com extrema agilidade. Utilizando métodos modernos, os traficantes de hoje em nada se assemelham aos românticos "Robin Hoods" do passado (Fonseca, 2000). Nos anos sessenta e setenta, os traficantes ocupavam um lugar de destaque nas comunidades onde se instalavam, em função da assimilação de algumas tarefas da alçada do Estado, principalmente segurança e assistência. Atualmente, este papel estatal continua sendo exercido; contudo, nota-se uma forte transformação no modelo deste "Estado": ao passo que antes a atuação destas lideranças se assemelhava àquelas dos governos de orientação populista, hoje vemos que este semelhança ao Estado se manifesta através do medo; o exercício do poder por parte dos traficantes, hoje, lembra em muito os métodos de repressão e de terror utilizados por Estados fascistas e ditatoriais. Esta lógica, tão comum em comunidades do Rio de Janeiro, já pode ser sentida em algumas comunidades de Porto Alegre, como no Campo da Tuca ${ }^{7}$, por exemplo.

Ler a violência urbana apenas como conseqüência do tráfico de drogas é muito simplório, e não condiz com a realidade. Uma leitura um pouco mais sofisticada precisa levar em conta aspectos históricos, por exemplo. Na adaptação cinematográfica de Ruy Guerra para "A Ópera do Malandro", de Chico Buarque, há uma cena muito interessante: enquanto a personagem Margot prepara-se para o show da noite, duas camareiras conversam enquanto limpam o teatro. Uma diz à outra que o preço da cocaína havia subido: “Um boneco de cinco gramas de cocaína pelo preço de duas cervejas! Assim eu não cheiro mais, nem pra remédio!'. A obra de Chico Buarque, ficcional, desenrola-se em um cenário absolutamente real: o Rio de Janeiro durante a segunda grande guerra. De fato, naqueles dias, podia-se comprar cocaína nas farmácias, a preços módicos. A proibição do uso de algumas substâncias é, pois, uma realidade recente na história brasileira.

\footnotetext{
7 - Em sua dissertação, ao descrever o universo de pesquisa, Fernanda Piccolo diz que escolheu o Campo da Tuca “(...) por ser esta área de mais fácil acesso, pois não há um controle tão rígido de quem entra neste local, por parte do crime organizado, como existe em outras vilas, por exemplo, o Morro da Cruz". Tal citação é interessante porque hoje, apenas três anos depois, a realidade é completamente inversa (Piccolo, 2001).
} 
Segundo Gilberto Velho, uma das principais características da pessoa usuária de drogas é justamente a ausência de características unificadoras que possibilitem a construção de um "perfil" do usuário de drogas (Velho, 1994). Para demonstrar isto, ele irá acompanhar, ao longo de três anos, um grupo de usuários de drogas da classe média alta carioca (Velho, 1998). Já Anthony Richard Heneman estuda os problemas vividos por uma tribo do Maranhão, onde o uso de maconha é visto com naturalidade (Heneman, 1994). Por fim, como exemplo final desta diversidade, tomemos o estudo de Fernanda Delvalhas Piccolo, sobre as trajetórias sociais de usuários de drogas no Campo da Tuca, em Porto Alegre (Piccolo, 2001). Comparados estes três estudos, encontramos apenas um elemento unificador: o uso de substâncias psicoativas. Pode-se perceber, portanto, que não existe um modelo fechado através do qual podemos descrever os grupos de usuários de drogas. Não existe "uso" de drogas, e sim "usos".

Os atravessamentos entre o mundo da droga e o mundo da violência são cada vez mais estreitos. Se nos anos sessenta e setenta o uso de drogas era relacionado ao movimento de contra-cultura, na atualidade ele é relacionado à criminalidade. É cada vez mais comum o discurso de que o usuário de drogas sustenta o traficante. Este, por sua vez, é demonizado, e visto como uma criatura maligna, capaz das maiores barbaridades (Zaluar, 1994; Moretzsohn, 2003). E, na tentativa de fazer a imagem do traficante inseparável da imagem do mal, meros peões do narcotráfico causam mais horror que os capitalistas que se locupletam com os estratosféricos lucros deste negócio milionário, devido ao fato de que são visíveis, estando carnal e perigosamente próximos de nós. Para a maioria das pessoas, a simples tentativa de se estabelecer relações que liguem a violência à ilegalidade do comércio de drogas, em uma comparação rasa com os problemas advindos da Lei Seca nos Estados Unidos, é motivo de escândalo. O moralismo ainda dá a tônica, em um debate que, salvo raras e louváveis exceções, sempre descamba para o lugar comum e para a superficialidade. Em face disto, um Projeto de Lei como o de número 7.134/2002, que versa sobre o fim das penas restritivas de liberdade aos usuários de drogas é visto como um grande avanço. Segundo Vera Malaguti Baptista:

O pessoal que propõe a descriminalização do usuário vai na vertente Posto Nove, falando para um público que já é descriminalizado, que é o usuário de classe média e de zona sul. E que eu não quero criminalizar, veja bem. Mas aí a 
contrapartida para esse discurso consentido é pena maior para o traficante. Nós não temos um problema de saúde pública, por alto consumo de drogas ilegais. Temos outros problemas muito maiores na frente: tuberculose, alcoolismo... Por onde a questão das drogas sangra literalmente é no tráfico. Então ou você tem isso de descriminalizar o usuário mas manter a criminalização do traficante, que virou uma categoria fantasmática, o traficante é o demônio, ele não tem casa, não tem mãe; ou então você tem o projetinho da embaixada americana, que é o "justiça terapêutica”, que diz: o usuário é uma vítima. E aí reproduz todo o positivismo do século XIX, e faz uma justiça que não apenas julga, ela também cura. Então obriga o usuário a ir perante o juiz, fazer teste de drogas, tem que se vestir bem, tem que ter notas boas. Um monstrengo positivista que voltou através dessa coisa. A descriminalização do usuário poderia ser o começo de uma legislação geral, mas como eles estão legislando para o Posto Nove, fica uma coisa perversa, porque quem já está descriminalizado vai ser descriminalizado e onde está sangrando, que é na periferia, aumenta-se a hemorragia. (Moretzshon, 2003)

Se por parte da classe média, existe toda um predisposição à execração da venda e do uso de drogas, nas outras duas extremidades da pirâmide social, a tolerância é, de um modo geral, e guardadas as especificidades, bem maior. Este estudo busca compreender o olhar de um grupo especifico de senhoras moradoras de uma vila popular de Porto Alegre. Mas, com respeito às razões para uma maior tolerância por parte das classes dominantes para com os vendedores de drogas, podemos nos reportar a um trecho de um artigo do jornalista Samuel Blixten, especialista em delinqüência econômica, que vai fechar esta parte da contextualização, jogando nosso tema da micro para a macro-esfera:

Os capitais do narcotráfico estão presentes nos processos de privatização das empresas públicas da América Latina e solucionam um verdadeiro problema para as atuais administrações: a obtenção de um fluxo permanente de divisas para cumprir os compromissos assumidos com os refinanciamentos da dívida externa. Tais necessidades de receita neoliberal atualmente exercida como concepção homogênea em todo o continente, multiplicaram as ações de lavagem, toleradas quase sem dissimulação. Esta realidade revela um duplo discurso e põe em questão os fundamentos da cruzada contra o narcotráfico. Põe em destaque até onde podem se compatibilizar com a lógica de mercado dominante, uma vez que a produção e a comercialização de drogas é um negócio dinâmico, com uma rápida capacidade de acumulação de recursos. (Blixten, 2003)

Segundo Blixten, as mesmas drogas demonizadas pela classe média - a partir de um discurso construído sobre uma base que mescla elementos de hipocrisia a formulações 
rasas tomadas de empréstimo junto à mídia - são vistas pelos "Senhores de Davos" como meros produtos mercantis. Os "Barões do Narcotráfico" são recebidos no Jet Set das finanças internacionais pela porta da frente, ao passo que a mera desconfiança de que o namorado da filha vende algumas buchinhas de cocaína para equilibrar o orçamento pode despertar o desespero em um pai de família da classe média. Ao que tudo indica, esta postura desapaixonada adotada pelos grandes financistas internacionais diante do negócio da droga guarda muitas semelhanças com a postura de muitos segmentos da base da pirâmide social no Brasil. A droga, para ambos, é apenas um bom negócio.

\title{
1.2 O Mundo do Envelhecimento
}

\begin{abstract}
(...) Exige-se do indivíduo estigmatizado que ele se comporte de maneira tal que não signifique nem que sua carga é pesada, e nem que carregá-la tornou-o diferente de nós; ao mesmo tempo, ele deve-se manter a uma distância tal que nos assegure que podemos confirmar, de forma indolor, essa crença sobre ele. Em outras formas, ele é aconselhado, a corresponder naturalmente, aceitando com naturalidade a si mesmo e aos outros, uma aceitação de si mesmo que nós não fomos os primeiros a lhe dar. Assim, permite-se que uma aceitaçãofantasma forneça a base para uma normalidade-fantasma. (Goffman, 1988)
\end{abstract}

O mundo está cada vez mais velho. Esta afirmação inicial diz respeito não apenas ao planeta em si, que se considerado na perspectiva da hipótese Gaia, é um ser vivo e como tal envelhece, mas também no sentido de seus habitantes. Com os avanços da medicina e do saneamento urbano, a expectativa de vida dos seres humanos cresceu enormemente. Acredita-se que no ano de 2030, pelo menos em muitos países do primeiro mundo, um terço da população terá mais de sessenta anos, ao passo que já no ano de 2150, este dado deve se estender ao mundo como um todo (ONU, 2000).

Tal dado teria tudo para ser comemorado, não fosse o fato de que as políticas sociais não se desenvolveram equilibradamente. Se por um lado temos um aumento da expectativa de vida da população mundial, por outro, percebemos que nossa sociedade não acompanhou esta transformação. Do ponto de vista econômico, nota-se uma crise profunda nos sistemas de aposentadoria em todo o mundo, obrigando governos a um reajustamento 
nos métodos de gerenciamento das contas dos sistemas previdenciários (Moraes, 2002). Do mesmo modo, a lógica de comprometimento financeiro para com os serviços da dívida externa, por parte dos governos de países não industrializados, faz com que os recursos necessários ao incremento dos programas de saúde voltados ao idoso (e à população de um modo geral), não sejam atendidos (Nunes, Mauro \& Chaves, 2003). Do ponto de vista do planejamento urbano, vemos cidades completamente despreparadas para acolher e incluir pessoas com idades avançadas, com necessidades específicas, como um sistema de transporte urbano melhor adaptado e espaços públicos projetados para as deficiências físicas inerentes ao processo de envelhecimento (Barreto, 1999).

(...) Deve ele (o indivíduo) aceitar tão profundamente a atitude do "eu" que é definida como normal em nossa sociedade e deve ser parte dessa definição a tal ponto que isso lhe permita representar esse "eu" de um modo irrepreensível para uma audiência impaciente que fica em semiprontidão à espera de uma outra exibição. Ele pode até mesmo ser levado a unir-se com os normais ao sugerir aos seus iguais que estão descontentes que o desprezo de que se sentem alvo é imaginário - o que, é claro, é provável em alguns momentos, porque em muitas fronteiras sociais as linhas são tão tênues que permitem a qualquer pessoa proceder como se fosse completamente aceita, e isso significa que será realístico orientar-se para signos mínimos, talvez não intencionais. (Goffman, 1988)

Para pensar o processo de envelhecimento na sociedade contemporânea, acreditamos ser importante partirmos do mesmo pressuposto do qual pensamos, agora a pouco, os "mundos da droga"; é preciso reconhecer que existe não um envelhecimento, mas sim “envelhecimentos”. Estes envelhecimentos serão tantos quantos forem as sociedades e culturas existentes, e dentro de uma mesma sociedade, encontraremos fatores que definirão estas diferenças: etnias, gênero, posição social, opção sexual, grau de escolaridade, etc. Quando Aline Iara de Souza estudou o envelhecimento e as estratégias de saúde e qualidade de vida na Vila Pitinga (Souza, 2002), foi de fundamental importância o conhecimento acerca da situação econômica, familiar, dos seus recursos terapêuticos, além de um estudo sobre o olhar que este idoso tem de si mesmo e suas opiniões sobre qualidade de vida. O que Souza descobre em sua pesquisa é que muitos dos preconceitos que construímos com relação ao idoso não se confirmam no contato com a realidade.

A ironia dessas recomendações não é o fato de se pedir ao estigmatizado que ele seja, pacientemente, frente aos outros, o 
que não lhe deixam ser, mas que essa expropriação de sua resposta possa ser a sua melhor recompensa. Se, de fato, ele tenta viver tanto quanto possível "como qualquer outra pessoa", e ser aceito "pelo que realmente é", então, em muitos casos, a posição mais inteligente a tomar é a de que tem um fundo falso, já que, em muitos casos, o graus de aceitação da pessoa estigmatizada pelos normais pode ser maximizado se ela aceitar com absoluta espontaneidade e naturalidade como se a aceitação condicional de si mesma, que ela procura não superar, fosse a aceitação total. (Goffman, 1988)

A recente aprovação do Estatuto do Idoso, em outubro de 2003, dá conta de um desejo consciente da sociedade brasileira como um todo. Há uma unanimidade no que diz respeito ao fato de que nossos idosos merecem um tratamento infinitamente superior àquele que vem lhes sendo devotado pelo Estado e pela sociedade como um todo. Neste sentido, o Estatuto, antes de tão somente formatar um conjunto de normas já consagradas, surge exatamente no sentido oposto, qual seja, o de constituir-se em um instrumento poderoso de pressão por mudanças que se fazem necessárias e urgentes (Ramos, 2004). Afinal, se o Estatuto dá voz a um conjunto de anseios conscientes de toda a sociedade, por outro lado, inconscientemente, a tolerância individual para com os idosos é ainda peça rara, e as ações de filhos que se preocupam de modo ativo com o bem estar de seus pais quando estes alcançam à terceira idade são motivos de louvor. A bem da verdade, deveriam ser via de regra, e não exceção. A cidadania das pessoas mais velhas é freqüentemente espezinhada, seja por despreparo estrutural, seja por preconceito individual (Loureiro, 1999).

Assim, mesmo que se diga ao individuo estigmatizado que ele é um ser humano como outro qualquer, diz-se a ele que não seria sensato tentar encobrir-se ou abandonar "seu" grupo. Em resumo, diz-se-lhe que ele é igual a qualquer outra pessoa e que ele não o é - embora os porta-vozes concordem pouco entre si em relação a até que ponto ele deveria pretender ser um ou outro. Essa contradição e esta pilhéria constituem a sua sorte e seu destino. Elas desafiam constantemente àqueles que representam o estigmatizado, obrigando esses profissionais a apresentar uma política coerente de identidade, permitindo-lhes que percebam $\log$ os aspectos "inautênticos" de outros programas recomendados, mas, ao mesmo tempo com muita lentidão, que não pode haver nenhuma solução "autêntica". (Goffman, 1988)

Os trechos citados nesta parte do trabalho foram extraídos do livro "Estigma: notas sobre a manipulação da identidade deteriorada", de Erving Goffman. Nesta obra 
magistral, Goffman busca analisar o problema da estigmatização a partir dos indivíduos onde este problema cala mais profundamente: nos portadores de deficiências, nos aleijados. O primeiro texto do livro traz a carta de uma jovem (provavelmente endereçada a um programa de rádio), que alega seu desespero diante do fato de não ter nariz ("Tenho um grande buraco no meio do meu rosto que amedronta as pessoas e a mim mesma...”). Assim como no caso desta jovem, o estigma do idoso - pelo menos do idoso que não possui recursos para a realização de cirurgias plásticas - está em sua face. O preconceito a que está submetido o idoso faz com ele seja considerado, de um modo geral, como incapaz, como um estorvo, como um peso, como lento do ponto de vista físico e intelectual, como incapaz de aprender. Estes preconceitos vão surgir automaticamente diante do fato de que o idoso possui não apenas um estigma, mas vários: suas rugas, sua postura corporal, seu assessórios (bengalas, óculos, vestimentas), seus cabelos. E diante desta multiplicidade de preconceitos, até mesmo a estratégia dos idosos mais favorecidos economicamente - a cirurgia plástica - vai ser vista como uma atitude indigna diante da velhice, pois se espera deste ser humano que sofra sua sina. Seu desejo de fugir do estigma como que irrita ao estigmatizador, que se sente roubado em seu desejo de rotular, de marcar, de estigmatizar.

\section{Descrição do Universo de Pesquisa}

Neste capítulo, busco situar o leitor no contexto geográfico, histórico, social e cultural onde a pesquisa foi realizada. Para tanto, optei por uma sistemática que poderia ser descrita com a utilização de uma dupla metáfora: um cronômetro e uma câmara filmadora.

Tomo, como marco zero o ano de 1952, início da ocupação do Morro da Cruz. Como fosse possível congelar o tempo, enquanto desloco o foco de minha imaginária câmera por mundo paralisado, parto para esta improvável viagem rumo ao específico. Tal viagem ocorre através do "zoom" de nossa metafórica filmadora, que tem como imagem inicial o panorama social, político, econômico e cultural do planeta, como que visto do espaço. À medida que nosso olhar vai se aproximando do universo específico, o detalhamento vai se tornando maior.

O objetivo final deste deslocamento de foco é demarcar o início de uma nova trajetória, não mais espacial, como na metáfora da câmera, mas temporal. A partir da 
"chegada" no Morro da Cruz, disparamos nosso "cronômetro", e a partir de agora iremos nos deslocar não mais no espaço, mas sim no tempo. Vamos nos mover de 1952 até os dias atuais, para compreender um pouco da história desta comunidade. Tentaremos, enquanto contamos a história deste microcosmo, iniciar já algumas tentativas de compreender a "Formação das Almas", desta comunidade, introduzindo alguns aspectos que serão detalhados mais adiante.

$\mathrm{Na}$ terceira parte, fechamos ainda mais o foco de nossa lente, para olharmos especificamente para o grupo das Caminheiras da Paz, que se reúne na Casa das Vós, e que é, enfim, o universo específico onde nosso estudo foi realizado. Para tanto, retornaremos uma vez mais no tempo, e nos locomoveremos ainda um pouco no espaço, para compreender como se deu o trajeto deste grupo de senhoras até os dias de hoje. Nossa viagem chega ao fim. Ou será o começo?

\subsection{O Brasil e o Mundo em 1952.}

Em 1952, os Jogos Olímpicos acontecem na Finlândia, em sua segunda edição depois da segunda guerra mundial. Há uma verdadeira explosão mundial de notícias acerca de contatos com OVNI's. Os padrões de beleza feminina incluíam tanto a ingenuidade chique de Grace Kelly quanto à sensualidade fatal de Rita Hayworth. O Rock'n Roll desponta como gerador de uma nova atitude, e um ano antes, em 51, Marlon Brando estrelava o clássico "Um Bonde Chamado Desejo”. Genne Kelly, ainda em 52, dança a canção-título do filme "Dançando na Chuva", e Chaplin estréia "Luzes da Ribalta".

Na Inglaterra, morre o Rei George VI, e Elizabeth II é proclamada rainha. Os EUA vivem à sombra do Machartismo, com a organização de comissões de investigação que acusam de atividades anti-americanas qualquer pessoa suspeita de ligação com movimentos ou organizações consideradas comunistas. E por falar em comunistas, do outro lado do planeta, na Ásia, o Tibete é anexado à China, vindo a desaparecer do mapa mundial enquanto nação independente. O líder Dalai Lama e boa parte da população buscam asilo na Índia.

\footnotetext{
8 - "A Formação das Almas” é o título de um clássico da ciência política brasileira, escrito por José Murilo de Carvalho, onde o autor busca analisar a construção do imaginário mitológica pós-república no Brasil.
} 
No campo da política internacional, o Pós-Guerra trás consigo todo um movimento de reorganização dos blocos internacionais. O mundo agora se divide entre os países alinhados com a União Soviética e os países alinhados com os Estados Unidos. Desenvolve-se no cenário mundial a chamada "Guerra Fria", que tem como características a disputa a partir do apoio militar diferenciado em conflitos localizados, a corrida espacial e a competição quanto a quem tem o maior arsenal nuclear. Neste ínterim, ainda em 52, os Estados Unidos explodem a primeira bomba de hidrogênio, com potência de 15 milhões de TNT (750 vezes mais potente que a primeira bomba atômica), e a Inglaterra anuncia que desenvolveu a sua versão da bomba atômica. O Plano Marshall direciona bilhões de dólares dos Estados Unidos para a Europa. A contrapartida européia se dá com a adesão em massa à OTAN (Organização do Tratado do Atlântico Norte), criada em 49, construindo laços de relação política, econômica e militar entre os países anticomunistas.

Os Estados Unidos intervêm em todas as partes do mundo que consideram ameaçadas pela expansão comunista. Estamos no meio das Guerras do Vietnã e da Coréia, ao passo que para a América Latina, a coordenação das ações militares é realizada através do Colégio Interamericano de Defesa, criado em 1950, devidamente alinhado com as proposições do chamado "Plano Truman", que defendia a "responsabilidade americana" quanto à definição de uma nova ordem mundial.

Um pouco mais ao sul, Fulgêncio Batista depõe o presidente Carlos Prio Socárras, e assume pela segunda vez a presidência de Cuba. Perón é reeleito presidente argentino, e Evita morre logo em seguida, provocando grande comoção nacional. Na Bolívia, a esquerda organiza uma contra-revolução com vistas a dissolver o golpe de estado levado a cabo pelos militares, e devolve o comando do país ao presidente eleito, Paz Estensoro.

No Brasil, Getúlio Vargas, eleito em 51, inicia um governo de feições nacionalistas. No ano de 52, aprova a Lei de Remessas de Lucro, obrigando as empresas multinacionais a reinvestirem no mínimo $10 \%$ de seu lucro líquido no país. Temos a criação do BNDE, a construção da hidrelétrica Paulo Afonso, e um forte incentivo ao desenvolvimento da indústria siderúrgica nacional. Em 53, um ano depois, será criada a Petrobrás. Tudo isto sob os rumores de uma intensa instabilidade política que irá culminar no suicídio de Getúlio, em 1954. 
Também em 52, é criada a Conferência Nacional dos Bispos do Brasil (CNBB). No futebol, o Brasil é campeão pan-americano, disputando a final contra o Chile. No cinema, temos a decadência da Vera Cruz e o lançamento do primeiro filme brasileiro colorido (Destino em Apuros). Na música, morre o cantor Francisco Alves, um dos maiores ídolos populares do país, considerado o "Rei da Voz". A música popular brasileira vê o surgimento das canções de protesto, que inicialmente e voltam contra os baixos salários, exigindo melhores condições de trabalho. Estas canções irão lentamente se unir às canções de homenagem à malandragem, que juntamente com as canções ufanistas de Ary Barroso, irão formar o caldo cultural da época, pelo menos no que diz respeito à música. Ainda que as táticas getulistas de cooptação e utilização da música como propaganda fossem extremamente eficientes, era possível ouvir pérolas como "Diploma de Pobre", gravada por Moreira da Silva ( “... Enquanto o filho do rico vai estudar/ Coitado do filho do pobre, vai trabalhar/ Coitado do pobre, que mal ganha pra sustentar/ Quatro ou cinco bocas que ficaram em seu lar/ Enquanto o filho do rico estuda/ E vai ser doutor/ O filho do pobre nasce e morre/ Trabalhador...”).

No Rio Grande do Sul, Lupicínio Rodrigues grava a clássica "Nunca" ("Nuncal Nem que o mundo caia sobre mim/ Nem se Deus mandar, nem mesmo assim/ As pazes contigo eu farei...”). Aldo Locatelli pinta os painéis da Igreja Santa Terezinha. O Internacional sagra-se campeão gaúcho, e Ernesto Dornelles, do PTB, é o governador do estado. Ainda em 52, é inaugurada a ponte sobre o rio Guaíba, obra coordenada pelo então Secretário de Obras Púbicas do Estado, o engenheiro Leonel Brizola, que à época tinha apenas trinta anos.

Brizola assume o cargo no governo do estado depois de ter sido derrotado nas eleições para prefeito de Porto Alegre por menos de mil votos por Ildo Meneghetti, que retorna à prefeitura depois de um afastamento de onze meses. Neste período, surge a Vila do IAPI, exemplo do modelo arquitetônico francês das cidades-jardins.

O processo de industrialização pelo qual passa o país faz com muitas famílias deixem o campo em busca de melhores condições de vida nas grandes cidades. O êxodo rural contribui para o surgimento de bolsões de pobreza.

Em Porto Alegre, começam a surgir as primeiras favelas. 


\subsection{Morro da Cruz - Um breve histórico.}

A comunidade do Morro da Cruz está situada no Bairro Partenon, Zona Leste de

Porto Alegre. Segundo dados disponibilizados pelo Instituto Leonardo Murialdo, o Partenon colabora hoje com 8,88\% da população de Porto Alegre, sendo a segunda região mais populosa da cidade, com cerca de 129.100 habitantes, dos quais 8,27\% são jovens entre 15 e 19 anos. Há cerca de 36.252 chefes de família na região, com renda média de 4,45 salários mínimos, sendo que 37,8\% destes percebem renda de até dois salários mínimos por mês. Destes 36.252 chefes de família, cerca de 10.544, 29,8\%, são mulheres, das quais 1.131, ou seja, 10,73\%, são analfabetas. Aliás, enquanto o analfabetismo em Porto Alegre atinge 3,3\% da população, no Partenon esta índice sobe para 4,1\%. Cabe ainda salientar que a FASC (Fundação de Assistência Social e Cidadania), através do Programa Educação Social de Rua no Centro da Cidade, abordou já seiscentos meninos e meninas em situação de rua. Segundo levantamento realizado, o Partenon fica em $3^{\circ}$ lugar na lista dos bairros com o maior número de jovens em situação de rua na cidade. A grande maioria iniciou sua vida nas ruas através da mendicância e do trabalho infantil na própria região. Vários deixam a mendicância como segundo plano em favor do ingresso no mundo das drogas e da prostituição.

Em 1952, o Morro da Guampa, como era chamado então, começou a ser ocupado, quando a área foi desapropriada para fins de habitação. Durante um bom tempo, tal ocupação se deu muito timidamente, de maneira a reproduzir os modos de vida e os modelos sociais de comunidades rurais, de onde era oriunda a grande maioria dos primeiros moradores. Outra parcela era formada por trabalhadores das docas, em sua grande maioria afro-decendentes. A água era proveniente de fontes abundantes, o que facilitava o plantio de milho, cana, batata doce, aipim e abóbora, além da criação de porcos. Este período também marca a chegada dos primeiros missionários da ordem religiosa dos Josefinos de Murialdo à comunidade, que em 1954 irão construir o Santuário de São José do Murialdo.

A Ordem dos Josefinos de Murialdo foi criada sob a inspiração de São Leonardo Murialdo, italiano nascido em Turim, em 1828, e falecido em 1900. Murialdo viveu em meio à efervescência da revolução industrial, não se abstendo de uma atuação religiosa 
vinculada à defesa dos Direitos Humanos das pessoas mais empobrecidas. Participou ativamente da organização das ligas operários em Turim, bom como da organização da imprensa operária. Uma de suas frases mais famosas é: "É maldito o trabalho que produz riqueza criando miséria, que entrega alma à máquina e a retira do homem”.

Em 1959, é firmado um convênio entre a recém criada Secretaria de Estado da Saúde, com o Instituto Leonardo Murialdo, para a criação do Centro Médico-Social São José do Murialdo. Este centro foi durante muitos anos uma das mais importantes escolas de saúde pública do Brasil, recebendo estudantes de medicina de todo o país. No início dos anos sessenta, o Morro começa a se organizar. Ruas são abertas, surge a iluminação por lampiões a gás, novos poços artesianos são perfurados, tudo com a participação direta dos moradores organizados.

A partir de 20 de março de 1960, o Morro da Guampa passa a se chamar Morro da Cruz. Este dia foi marcado por um evento de proporções messiânicas: os moradores da comunidade, juntamente com os religiosos, deixaram o Santuário de São José do Murialdo carregando uma cruz de eucalipto com treze metros de altura, levando-a até o topo morro, numa caminhada absolutamente heróica. Através disto, é possível perceber o prestígio e a influência dos religiosos murialdinos nesta comunidade desde os primeiros dias. No fim dos anos sessenta, mais precisamente em 1968, é erguida a Escola de Primeiro Grau Incompleto Padre Cornélio Tedesco, sob a coordenação do Instituto Leonardo Murialdo. Mais tarde, esta escola irá se tornar o Centro Infanto Juvenil, conhecido como "coleginho".

A partir dos anos 70, o processo de ocupação do Morro da Cruz se acelera. Fugindo do aluguel, muitas pessoas passam a ocupar áreas, construindo pequenas casinhas de madeira. Tal processo desordenado trouxe novos problemas ao Morro, como o acúmulo de lixo e a contaminação das fontes água. Diante da exacerbação destes problemas, e também como fruto natural do processo de organização da comunidade, surge, em 1978, a Associação Comunitária do Morro da Cruz (ACOMUZ).

Também durante a década de 70, as quadrilhas de assaltantes e de vendedores de drogas passam a fazer parte da rotina do Morro da Cruz. Uma das mais importantes foi liderada por Anão. Anão era um bandido romântico, que exercia uma liderança comunitária com forte cunho populista e assistencialista. Cuidava da segurança do Morro, muitas vezes de maneira cruel, mas também era a ele que se recorria quando alguém precisava de um 
remédio mais caro, ou mesmo quando faltava comida. Morto pela polícia em 15 de setembro de 79, seu enterro foi um evento até hoje lembrado: centenas de pessoas foram despedir-se do líder, desafiando o establishment ao prestigiar um fora-da-lei em plena ditadura militar. Durante muitos anos, uma bandeira preta foi afixada à cruz no alto do morro, sendo trocada todo dia 16 de setembro, em sinal de luto e respeito pela data de aniversário do enterro de Anão. Entre os anos setenta, oitenta e noventa, pelo menos três dos mais importantes traficantes de drogas do estado habitaram o Morro da Cruz: Anão, Carioca e Jorginho da Cruz.

A partir dos anos 80, ensaia-se um novo tipo de liderança, mais alinhada a grupos políticos, e interessada em trazer benefícios à comunidade. A luta pela água, por exemplo, detonada em 83, rendeu frutos em 84. A luta por ônibus que subissem o Morro, por escolas, postos de saúde e espaços de reuniões dos moradores, todas deram algum resultado. Foi uma década de muitas conquistas e muita organização, onde as lideranças da comunidade, extremamente à vontade em uma cultura populista e clientelista, sabiam como se mover em meio ao emaranhado institucional dos governos estadual e municipal, além de conseguir certos favores junto a alguns vereadores.

Neste período, ainda nos anos oitenta, são construídos vários espaços de cidadania no topo do Morro da Cruz. A creche fica pronta, o galpão para eventos sociais, artísticos e comunitários, a capela situada exatamente no topo do morro, e uma casa onde inicialmente seria a creche. A escolha do topo do morro para abrigar vários equipamentos do Instituto Murialdo, dispostos em uma pequena área, não foi gratuita. Padre Ângelo sonhava em tornar aquele espaço um ponto turístico da cidade. Para tanto, direcionou os investimentos em obras, optando por centralizar ao máximo os espaços comunitários construídos pelo Instituto naquela região. Tal desejo, no entanto, sempre esbarrou no medo e no preconceito que afasta as pessoas não só do Morro da Cruz, mas dos bairros de periferia de um modo geral.

Com a morte de Anão, a liderança do tráfico no Morro da Cruz (e conseqüentemente em Porto Alegre), passa às mãos de Carioca, que mantém acesa a tradição dos heróis bandidos no morro. Em pleno final dos anos 80, já com o advento do Estado Democrático, as ações com vistas à prisão de Carioca foram acompanhadas de eventos de truculência e desrespeito aos mais fundamentais direitos humanos. Com a 
justificativa de prender Carioca, a polícia invadiu casas sem mandato e sem autorização dos moradores, impôs revistas violentas e indiscriminadas a toda e qualquer pessoa, incluindo crianças e idosos, além de bloquear os acessos ao morro, evitando a entrada e saída de moradores. Ao contrário do que dizem da polícia, há uma quase unanimidade entre os moradores acerca de nunca terem sofrido nenhum tipo de violência por parte dos assaltantes e traficantes que viviam na comunidade. Os comentários positivos sobre estes líderes são ouvidos mesmo de pessoas que desaprovam as atividades por eles levadas a cabo, como alguns religiosos, por exemplo.

Os anos 90 assistiram uma radicalização e posterior burocratização do processo de participação popular, não só no Morro da Cruz, mas em toda a cidade de Porto Alegre. Intensificam-se instâncias como o "Orçamento Participativo" e o "Congresso da Cidade". Na contramão deste processo, o Morro da Cruz chegou a ter, em algum momento, cinco associações de moradores, cada qual ligada a diferentes grupos e personalidades políticas. A fragmentação criou um fenômeno de esvaziamento da legitimidade das lideranças do morro, bem como um afastamento destas lideranças da comunidade em si.

Em 1993, o Centro de Saúde Murialdo deixa seu prédio no pé do Morro da Cruz, transferindo-se para o endereço que ocupa ainda hoje, junto ao Sanatório Partenon, na avenida Bento Gonçalves. O grande prédio da rua Vidal de Negreiros vai ficar fechado até o fim dos anos 90, quando irá reabrir como o Centro de Formação Profissional Leonardo Murialdo, resgatando uma antiga dívida da instituição para com a comunidade: investir no ensino profissionalizante. O CFPMur constitui-se em um espaço de socialização e de promoção dos Direitos Humanos e da cidadania voltado aos adolescentes e jovens adultos.

Atualmente, o Morro da Cruz é reconhecido em toda a cidade por realizar, desde os anos sessenta, sempre às Sextas-Feiras Santas, a encenação da Paixão de Cristo, que mobiliza a comunidade e leva centenas de pessoas para o morro. Além disto, o morro é também o berço de um famoso grupo de senhoras que produz roupas que levam a marca do Morro da Cruz, a partir da reciclagem de matérias têxteis. Na esteira desta experiência de sucesso, inúmeros investimentos em projetos alinhados com os preceitos da chamada "Economia Solidária" vêm sendo levados a cabo na região, com resultados ora positivos, ora nem tanto. Para fomentar estas iniciativas, o Instituto Murialdo transformou o galpão situado ao lado da creche, no topo do morro, em uma incubadora de projetos sociais, que 
acolhe hoje a Grife Morro da Cruz, uma linha de produção de cosméticos especialmente desenvolvidos para afro-decendentes, um grupo de produção de doces e salgados, e a Grife Afro-Cruz, que produz roupas inspiradas no imaginário das religiões afro-brasileiras.

\subsection{A Casa das Vós e as Caminheiras da Paz}

A história das Caminheiras da Paz começa alguns anos antes da adoção deste nome, e até mesmo antes do surgimento da Casa das Vós. A gênese deste grupo está no clube de mães que surge praticamente junto com o Centro Infanto-Juvenil Padre Cornélio Tedesco, que a comunidade chama carinhosamente de "coleginho". Tal grupo inicia suas atividades no início dos anos setenta, reunindo as mães das crianças que freqüentavam o coleginho a esta época. Segundo relatos, este grupo desenvolvia atividades lúdicas e assistenciais, que incluíam a busca sistemática de recursos junto à sociedade portoalegrense; a distribuição de "sacolões"; a preparação de um "sopão" que era servido às famílias mais pobres, e também da merenda das crianças; a confecção de acolchoados, entre outras atividades. Tal grupo reuniu-se sistematicamente no coleginho até que a creche do topo do morro ficou pronta, graças a uma campanha de mobilização e arrecadação de recursos onde o grupo de mães cumpriu um papel fundamental.

Com a conclusão da obra, uma parcela das mães que se reunia no coleginho passa a utilizar uma sala nos fundos da creche. Tal deslocamento se deve em parte ao fato de que a creche ficava mais perto de casa de muitas daquelas senhoras, e em parte porque o cuidado das crianças dependia do trabalho voluntário destas senhoras.

Nesta época, o topo do Morro da Cruz já contava com a creche, com um galpão ao lado da creche, com uma pequena capela exatamente no topo do morro, e com uma casa que havia sido construída num terreno adquirido pelo Instituto Leonardo Murialdo. Tal casa, de tamanho médio, foi inicialmente construída para abrigar a creche. Porém, acabou tornado-se pequena antes mesmo de ser utilizada. Deste modo, esta casa serviu, durante

certo tempo, como refúgio para o Padre Ângelo Costa, que nesta época era o presidente do Instituto. 
Com o tempo, a ampliação da creche se tornou necessária, principalmente para incorporar funções de berçário. Para tanto, a sala que era utilizada pelas senhoras oriundas do coleginho precisou ser desocupada. Neste momento, acontece a transferência das atividades que até então aconteciam nos fundos da creche para a casa que historicamente havia sido o refúgio do Padre Ângelo Costa. O grupo que se desloca para a casa - originado do grupo de mães que foi criado no início dos anos setenta, ainda no coleginho - é composto por senhoras que não são mais apenas mães. Usando uma tradução literal do termo inglês, elas agora são "grandes mães"; são avós.

Estamos no início dos anos 90, e é criada a Casa das Vós: um espaço de convivência para as senhoras da terceira idade, moradoras do Morro da Cruz. Trata-se de uma casa bege, de material, com três peças e um banheiro, cercada por um alto muro de tijolos. É nesta casa que se reúne o grupo conhecido como Caminheiras da Paz, constituído por cerca de vinte senhoras com idades entre 50 e 90 anos, que se encontram duas vezes por semana para produzirem tapeçarias, roupas e acolchoados, ou simplesmente para estarem juntas. Grande parte destas senhoras é oriunda do interior, ou até mesmo de outros estados, tendo chegado ao morro entre os anos 70 e 90 . O grupo realiza também atividades culturais e de recreação, e conta com a coordenação e apoio de uma assistente social cedida pelo Instituto Murialdo.

\section{Interregno}

Por volta de duas e meia da tarde, eu e Nice saímos do Centro de Formação Profissional Leonardo Murialdo (CFPMur), rumo à Casa das Vós. Decidimos subir o Morro de ônibus, então fomos à parada e pegamos o Santa Maria, que estava relativamente vazio àquela hora da tarde. Podíamos ter pego o "Morrão", que é um ônibus circular gratuito que sobe até à cruz, mas ele costuma demorar bastante.

Trabalhei com a Nice por cerca de um ano. Ela é Assistente Social do Instituto Leonardo Murialdo (ILEM), e traz consigo uma experiência profissional de muitos anos. É ela que coordena o grupo "Caminheiras da Paz", que se reúne duas vezes por semana na Casa das Vós, centro de convivência ligado ao ILEM.

Descemos na parada mais próxima do topo do morro, e subimos por uma grande escadaria de degraus muito largos. No caminho, passamos por muitos moradores, inclusive alguns adolescentes 
com os quais trabalhei quando fui educador de Direitos Humanos no CFPMur. Um deles me cumprimenta erguendo uma pequena espingarda de chumbinhos.

Chegamos ao topo do morro. Ali se pode subir no terraço de uma capela, de onde se tem uma vista maravilhosa da cidade. É no topo desta capela que anualmente acontece, na Sexta-Feira Santa, o final apoteótico da tradicional encenação da Paixão de Cristo, levada a cabo por esta comunidade. Do lado esquerdo da capela, a creche e a incubadora de projetos sociais, onde fica a famosa Grife Morro da Cruz, além de outros projetos de economia solidária. E finalmente, bem em frente à cruz que dá nome ao morro, a Casa das Vós, para onde nos encaminhamos.

A casa é pequena, de material, cercada por um alto muro de tijolos. Destaca-se à primeira vista uma grande antena de rádio, que no passado era utilizada por uma empresa de ônibus. Entre o muro e a casa, um pequeno espaço de pouco mais de dois metros. Dentro da casa, nos espera um alegre grupo de senhoras, com idades entre sessenta e noventa anos. Há também algumas poucas crianças, provavelmente netas de algumas das senhoras ali presentes, além de um jovem, que descubro posteriormente tratar-se de um frater da Ordem dos Josefinos de Murialdo, mantenedora do ILEM.

O grupo é animado. Quando chego, várias trabalham em tapetes coloridos, feitos de retalhos de tecidos. Fazem muitas piadas de caráter sexual, comigo e com o frater. Brinco de volta, e percebo que o jovem religioso demonstra tanto "jogo de cintura” quanto eu.

Chega o momento em que Nice vai explicar o motivo de minha presença ali. É um momento tenso, pois por várias vezes discutimos (Nice e eu), quanto à necessidade de se colocar já desde o início o real objetivo da minha presença entre as vós. Chegou a hora de decidir. Na dúvida, opto pelo caminho da ética, e coloco toda a realidade: sou estudante de Ciências Sociais, e desejo fazer um estudo sobre a visão que estas senhoras têm dos consumidores e vendedores de drogas ali no Morro da Cruz. Explico-lhes que atuo nesta área há alguns anos, e que nunca me dediquei a estudar ou trabalhar com pessoas que não usam drogas. Termino minha fala, e percebo que o ponto é polêmico. As senhoras conversam entre si, e então decido colocar-me à disposição para esclarecer dúvidas sobre minha pesquisa. As perguntas fluem, ora sobre minha pesquisa, ora sobre dúvidas pessoais. Algumas senhoras relatam histórias contundentes, de mortes e prisões. Dona Maria José, que está sentada ao meu lado, e que descubro posteriormente ser a senhora de mais idade no grupo, me convida para ir até sua casa. Não perco tempo: pego minha agenda, e marco com ela um encontro para quinta-feira de manhã. Minha primeira entrevista já está marcada.

Logo depois, sou levado a conhecer o resto da casa. Possui três cômodos. O primeiro, onde aconteceu nossa conversa, é o maior, com duas grandes mesas e muitas cadeiras, além de duas máquinas de costura e uma de overloque. Existem dois murais, com muitas fotos de senhoras do 
grupo. Três grandes armários de cores diferentes, e muitos enfeites artesanais pelas paredes. Destaque para duas santas: uma pequena Virgem Maria com cerca de vinte centímetros, ricamente vestida, e uma santa de cerca de um metro, que descubro ser uma imagem de Yemanjá disfarçada, para que os padres não soubessem sua verdadeira identidade. Esta informação me é passada por Dona Maria José ao pé do ouvido, para que o frater não ouça.

Na peça dos fundos existem telhas quebradas, por onde entraram assaltantes. Também na sala intermediária pode ser visto o estrago provocado numa das janelas. Uma das senhoras me relata que “eles” levaram tudo o que havia de alumínio, além de louças e talheres. Esta senhora usa os termos "eles" ou "drogados", e nota-se um certo rancor em sua voz, e não se mostra aberta ao diálogo. Tento ir um pouco além, mas ela se esquiva.

No pátio, Dona Lúcia me chama a atenção para os locais onde costumava encontrar seringas, que eram recolhidas e enterradas. Mostra-me ainda diversos buracos feitos no muro. As senhoras não sabem porque "eles” fazem isto. Eu conheço o ritual de uso de cocaína injetável, e sei que estes buracos são fundamentais em função da "paranóia”, que surge como fruto da alteração da química cerebral em conjunção com os riscos reais inerentes ao rito. Mas opto por abster-me do comentário.

Entramos novamente na casa, onde converso mais um pouco com Dona Maria José, acertando os detalhes da visita: levarei uma cuca, e ela fará um café preto. Acompanho as Caminheiras da Paz em uma oração feita antes do café da tarde, e deixo o local acompanhado por Nice e pelo frater, combinando meu retorno na outra semana. Ainda passamos pela incubadora, antes de eu me despedir de Nice, agradecendo o apoio recebido. É hora de retornar à universidade.

\section{4. "Lendo o Baralho"}

No peito dos sem peito uma seta E a cigana analfabeta lendo a mão de Paulo Freire.

Beradêro - Chico Cézar

Dona Márcia conta que quando chegou ao Morro da Cruz, logo ao descer do caminhão em que veio junto com sua mudança, foi recebida por um grupo de traficantes. Eles pediram que ela e seu marido descessem do caminhão, "e já leram o baralho". 
Esta expressão me agradou muito. "Ler o baralho" remonta a atividade das ciganas, que através de técnicas secretas, passadas de mãe para filha, conseguem ler os significados oraculares presentes nas cartas deitadas à mesa pela mão do consulente. Tal expressão me agrada muito, em face da metáfora que podemos fazer com o ofício do etnólogo. Afinal, a cigana não pode fixar-se no significado intrínseco de uma única carta, mas precisa interpretar as relações entre o conjunto de cartas em frente aos seus olhos. A "morte", por exemplo, ao lado da carta do "namorado", em dependência ainda da pergunta

feita pelo consulente, pode perfeitamente significar o fim de um relacionamento, e não a morte física de alguém. Do mesmo modo, o antropólogo não pode satisfazer-se com uma leitura superficial e apressada dos dados que colhe em seu trabalho de campo. Muitas vezes, um sentimento manifesto em uma entrevista precisa ser cruzado por uma série de outras informações que irão surgir (ou que já surgiram) ao longo do trabalho de pesquisa.

Neste capítulo, tentarei finalmente cruzar as informações que colhi através de exercícios de observação participante e de entrevistas feitas com três informantes. O número, longe de ser o ideal para uma pesquisa mais séria, foi decidido a partir da percepção de que não seria possível ir muito além disto, em função do pouco tempo disponível, pois preferi aprofundar um pouco mais com cada uma delas, do que realizar várias entrevistas, todas muito superficiais. Optei ainda por não fazer o exercício de construção de personagem, ou de transcrição completa dos diálogos. Minha opção foi a de dividir este capítulo em quatro partes: "As Histórias", "Os Olhares”, “As Relações” e "Os Mitos". Para cada um destes temas de investigação, utilizarei trechos da fala de minhas informantes, de modo a fazer com que suspeitas e depoimentos dialoguem entre si, e com as teorias e referências em outras obras, sejam elas acadêmicas ou não.

Que um número maior de dúvidas que de respostas surjam deste exercício, será a prova maior da riqueza deste assunto: se assim não for, será a prova não do contrário, mas de que o trabalho foi por demais insuficiente.

\subsection{As Histórias}

Aqui era uma maloquinha; não tinha luz, não tinha água... Então... Tinha só uns capim na porta. Não tinha cerca, nada... Aí 
tinha um beco aqui atrás, onde morava o Ciganinho, ali... E era tráfico de droga aqui, né? Então, daí, quando cheguei de noite aqui com o caminhão - porque quando o meu marido comprou eu não vim junto - daí quando eu cheguei de noite, a nossa recepção aqui, foi eles - os traficante, né? - essa minha comadre, eles, a minha comadre com uma lata assim, que ali ela tinha as paranga de maconha, uns negócio ali. Foi essa a recepção. Eles que vieram ali no caminhão. Daí mandaram a gente descer, né, e já leram o baralho, né, de como é que era, né: Ela... Era... É... "Aqui, vocês podem morar aqui, vocês... Vocês se dão bem com a gente se vocês não virem e não sabem, né?”. E realmente, eu moro aqui até hoje, nunca, graças a Deus, assim ó: criei meus filho aqui, essa minha mais velha fez segundo grau, vinha do colégio uma hora da manhã, nunca, nunca, nunca, nunca aconteceu nada. Mas é aquela coisa, né; a tal "Lei do Silêncio": tu não viu e tu não sabe. (Dona Márcia)

As histórias sobre o tráfico de drogas no Morro da Cruz são sempre contadas com muita naturalidade, e até com algum orgulho. Não necessariamente os relatos que envolvam drogas incluem a violência. A própria declaração de que era importante respeitar uma "Lei do Silêncio" não parece comportar um tom de denúncia sobre uma arbitrariedade; parece mais uma fala sobre um acordo cumprido sem esforço. Diferentemente do que percebemos em outros bairros da cidade, o envolvimento com a violência e com o tráfico de drogas não é visto como motivo de vergonha, não resultando, portanto, em uma negativa de se partilhar histórias. Como quando Dona Maria José me contou sobre seu falecido marido, que era vendedor de maconha:

Dênis: E ele vendia maconha, é? Isto me interessa um monte, Dona Maria. A senhora se incomoda de falar disso?

Dona Maria: Eu não!

Dênis: Não? Não tem problema?

Dona Maria: Não; ele era maconheiro mesmo. Como é que eu vou dizer que não era? E ele não era feio. Mulherento, filho... (...) Tinha uma rapariga aí no meu pé. E eu trabalhava. Aí nesse dia eu não fui...

Dona Maria José era a primeira senhora que eu entrevistava individualmente. Naquele momento da entrevista, eu estava começando a acreditar que talvez eu estivesse perdendo tempo, pois toda e qualquer tentativa de ingressar no tema de minha pesquisa era frustrada. Dona Maria estava muito mais interessada em me contar os acontecimentos da noite anterior, quando ela visitou alguns amigos, do que falar do passado. A inexperiência fez com que, por alguns momentos, eu acreditasse que seria tudo uma perda de tempo. 
Quando o relato sobre a venda de maconha surgiu, me pegou tão desprevenido que quase ponho tudo a perder com minha reação.

Dona Maria: Teve uma vez que eu levei um susto: Tinha o Seu Negrão. Já morreu. Era um mulato. O Seu Negrão uma vez atirou nele. Mas o santo dele era tão bom, que não acertou nada. Nada assim de tiro, nada. Aí eu disse: Ih, minha nossa Senhora, vai morrer!". Tu sabe que vinha gente de tudo quanto era lado comprar maconha dele?

Dênis: Isto a mais ou menos quanto tempo atrás?

Dona Maria: Um ano, dois anos... É, porque depois eu tirei ele dessa coisa. "Se tu quer que eu fique contigo pra te cuidar, troca esta porqueira!". Mas ele... Quando ele morreu eu ainda achei um pacotinho ali. Ah, minha Nossa Senhora!

Novamente, as histórias de violência contadas sem nenhum traço de vergonha, vergonha esta que seria normal em se tratando de senhoras de outras regiões da cidade. Diferentemente de outras senhoras na mesma faixa de idade (Dona Maria José tem noventa anos), a naturalidade com que se trata o tema "droga" é realmente impressionante.

Daí aconteceu que o mais novo deles tudo, ele sempre trabalhou, mas sempre usou droga, né? Só que ele não incomodava... Não incomodava nada... Usava isso aí, ia pra casa, ia pro trabalho, voltava... Mas quando foi de repente, pegaram ele num ônibus, junto com um colega dele que tava chapado, e que usava assaltar os ônibus. E o guri começou a encarar pra ele... É até o Gordo, o filho de uma comadre minha... Ele tá preso até agora... Começou a olhar pro cobrador, e o cobrador se ligou que eles estavam os dois chapado, né? E nisso o outro viu, passou a loló pro meu guri, né? E ele foi passar a roleta. Daí o brigadiano tava ali e prendeu ele. Daí foram presos. O meu guri não chegou nem a ficar dez dias. $\mathrm{O}$ menino era quinze dias, mas ele não chegou a ficar dez dias, porque não tinha... Só apenas tava com um paninho de loló e o outro escondeu... Até inclusive o vidro. (Dona Cleusa)

Dona Cleusa conta a história da prisão de seu filho. Ela possui um olhar extremamente crítico acerca da ação policial, mas esta crítica não faz com que ela negue o envolvimento do filho com drogas. A naturalidade encontrada anteriormente desaparece, não obstante o fato de que este filho está bem, tendo deixado as drogas, levando hoje uma vida pacata: trabalha, é casado e tem um filho. Em contrapartida, o filho mais velho terminou por suicidar-se. Segundo Dona Cleusa, tudo devido ao uso de drogas: 
Quando ele se matou ele tava comigo, porque daí ele viveu um pouco com ela e voltou. Aí eles tinha uma casinha ali. Aí eles moravam ali, ele saía a trabalhar, quando chegava ela tava com a casa cheia de homem fumando, cheirando. Daí brigavam, brigavam, quebravam todo telhado. Quando foi um dia apareceu a casinha queimada. É... Acho que foi ele mesmo que queimou. Eu acho que foi. Ele nunca confessou pra mim. Porque ele tinha a mania de não esconder nada. Nada, nada, nada. Mas ele não chegou a me confessar que foi ele que queimou a casa. Até inclusive ele falou pra irmão dele: "Ah, eu fiz uma sujeira muito grande aí..." Pegou e foi embora pra Santa Catarina. Santa Catarina, foi morar com uma irmã minha, exatamente numa casa que o tio dele bebia. Daí não tinha... Já não tinha isso aí... Mas começou a beber, beber, beber, e começou a brigar entre eles. Minha irmã mandou de volta. Ele tirou um pouco pra ver se aliviava, né? Aí ele venho... Daí ele se afundou mesmo na droga. De novo. De tudo. De tudo que acontecia ele tava junto. Só não matou, graças a Deus, eu nunca soube que matasse, que roubasse, estuprasse, essas coisas não, mas a droga assim... Ficava muito valente, ficava muito valente. Ninguém podia olhar nem... Nem eu não podia olhar pra cara dele que ele já... Inclusive no dia que ele se matou, eu não podia abrir a janela pra ver se ele tava muito chapado, porque se ele me visse ele... Ficava assim estúpido. Ele era um filho que não respondia nada, mas... (Dona Cleusa)

As dificuldades para pronunciar algumas palavras são sérias: "Drogas", por exemplo, só é dito a muito custo. Prefere dizer “Isso âै" ou "essas coisas ẩ”. Deste modo, podemos perceber que a naturalidade presente no discurso de Dona Maria José e de Dona Márcia não se repete em Dona Cleusa. A perda de um filho parece ter sido por demais traumática, construindo um contraponto para um discurso recorrente de que os sentimentos maternos deterioram-se em função das altas taxas de mortalidade em alguns bairros de periferia, como uma estratégia de proteção das mães ${ }^{9}$. O relato do suicídio do filho traz ainda alguns outros elementos que demonstram o quanto existem bloqueios:

Aí eu trabalhava aquela época na creche, era um sábado, daí, ai, eu tava tão cansada... Aí a gente ainda foi fazer faxina, que a Márcia era a diretora naquela época. Eu peguei, fui fazer faxina, eu e ela, no sábado, pra deixar tudo limpinho, a creche, que era pouca gente, e eu fiquei muito cansada, e eu tenho pressão alta há muito tempo né? Daí eu tomei o remédio da pressão. A Jéssica, a minha filha que tem nove anos, também era nenê, tava com febre, daí ela pegou... Mediquei ela... Era duas

\footnotetext{
9 - Não conheço nenhum estudo que fale deste tema, mas nos anos em que venho atuando em instituições de assistência social, já me deparei muitas vezes com este discurso recorrente, que dá conta de que existe um mecanismo subconsciente que faz com que as mães de jovens moradores de bairros violentos tenham um abalo naquilo que popularmente conhecemos como "instinto materno".
} 
hora da madrugada, tava lá comigo... Até duas hora ele entra e dorme. Daí ele não voltou a dormir. Aí quando foi de manhã minha guria chegou do som que ela tinha ido: "Ah mãe... Olha o mano aqui". Eu disse: "Deixa ele. Ele bebeu. Parece que ele tá caído", achei né? Alguma coisa, né? Mas ele nunca foi de cair... "Ele tá bêbado", eu disse. "Não, ele não tá bêbado, ele tá morto". Eu disse: "Não, ele tá bêbado", e ela "Não, tá morto!". Parece que... A gente tá acordando àquela hora, né? Era em torno de cinco horas, acho... Aí a Jéssica, minha nenê, né? Ela era bem pequenininha. Daí ela chamava ele de Dadá, por causa da filha dele, que ele chamava de Dadá. E ela disse: "Ah mãe, a mana tá dizendo que o Dadá tá morto”. Aí que em me liguei, né? Aí depois eu não me lembro quase de nada. Daí ele se enforcou. Se eu não me engano assim, dentro do pátio, né? Num abacateiro. (Dona Cleusa)

As histórias envolvendo drogas e violências são contadas de maneiras diferentes por cada uma das senhoras. Mas existem traços de unidade, como o simples fato de que todas elas possuem histórias muito próximas para serem contadas. Não se trata de histórias envolvendo primos, vizinhos ou parentes distantes, mas histórias sobre filhos, maridos. As histórias de Dona Márcia não envolvem o uso ou a venda de drogas por parte de nenhum parente direto, mas, em contrapartida, ela demonstra ser, de todas as informantes, a que mais proximidade teve com este universo:

Daí eu vim morar ali, né? Daí, né... Lá em Cachoeirinha a gente não tinha contato com isso aí, né? Tá, daí eu cheguei aí primeiro dia... Eu cheguei de noite. No outro dia de manhã: uma maloquinha; chovia que nem na rua; só chão, assim. Ah! Precisava tu ver, um horror! Não tinha luz, não tinha água, não tinha banheiro; tinha uma patente velha lá no fundo. Uns capim de elefante que era aqui pra trás. Onde tem até a casa da minha guria, ali, era tudo tráfico, tudo droga, ali. Era tudo aberto, era tudo... Tava... Daí de manhã eu levantei assim pra terminar, lavando a louça, comida ali, aí venho um assim por trás, me pediu fogo na minha janela. Bah! Aí eu me apavorei! Não, e pra ajudar ainda de tarde deu um tiroteio entre... O meu marido... O meu marido tava lá na Carris. Daí diz que disseram: “Ah, deu um tiroteio lá em cima, lá no morro, na última maloquinha”. Ele subiu correndo lá de baixo lá pra... De certo... Claro, pensando, ele pensando, né?: "Ela deve tá apavorada". Bom... A única coisa que eu fiz, daí, essa minha comadre: "Ó; pega as criança, pega eu tinha a minha guria mais velha só - pega e vai pra baixo da cama”. Então foi o que eu fiz, né? Fui pra baixo da cama. Daí era tiroteio entre eles. Daí... Eles Depois... Daí eu fui me acostumando aos poucos, né? Eu precisava de morar aqui, não tinha outro lugar pra ir. (Dona Márcia) 
Contar histórias é uma característica destas senhoras (Souza, 1999), de modo que já no primeiro dia de presença no campo, fui convidado para uma visita que acabou resultando em uma entrevista. Os relatos de etnólogos acerca das dificuldades para estabelecer vínculos com informantes e marcar entrevistas (Foote-White, 1990; Geertz, 1989; Gaspar, 1985), não encontram paralelos neste universo. Minhas informantes foram sempre absolutamente generosas ${ }^{10}$, o que me remete às observações feitas por Cláudia Fonseca em seu trabalho sobre a fofoca no Morro da Cruz (Fonseca, 2000). Ao que parece, o desejo de contar uma boa história, de preferência com algum sangue, ainda faz parte do ethos desta comunidade.

\subsection{Os Olhares}

10 - Outro trabalho onde podemos encontrar relatos sobre a facilidade de construção de vínculos entre o etnólogo e o informante, é a etnografia de Flávia de Mattos Motta sobre a "faceirice" entre um grupo de terceira idade da LBA. Talvez exista um componente etário que torna estas senhoras boas contadoras de histórias. 
Aí no outro dia tu cobra deles, e eles não lembram de nada. "Ah tia, nós tava ratiando ontem". (Dona Márcia)

Interessa-me muito o olhar destas senhoras acerca do mundo das drogas, dos usuários e dos vendedores. Percebi, desde minhas primeiras incursões ao Morro da Cruz, ainda em 2002, que os discurso tradicional sobre o tema das drogas não se repetia naquela comunidade $^{11}$. Desde então, pergunto-me sobre as razões para que isto ocorra deste modo. Seria por uma proximidade cotidiana com o mundo da droga? Por razões mitológicas? Pergunto-me até mesmo se minhas impressões a este respeito não estariam equivocadas, e que talvez eu tenha tido contato com um número inexpressivo de senhoras ao longo deste período, o que tornaria esta impressão nada mais do que uma simples impressão. Por fim, penso inclusive que talvez este discurso seja superficial, escondendo camadas mais profundas, onde o olhar talvez se aproxime daquele manifestado pelas senhoras da classe média:

Dênis: Isto a mais ou menos quanto tempo atrás?

Dona Maria: Um ano, dois anos... É, porque depois eu tirei ele dessa coisa. "Se tu quer que eu fique contigo pra te cuidar, troca esta porqueira!". Mas ele... Quando ele morreu eu ainda achei um pacotinho ali. Ah, minha Nossa Senhora! Aí tem uma senhora ali - ela tem os filhos tudo maconheiro - ela mora ali pra baixo. Ela que levou a maconha pro marido dela. Agora passa por mim e faz que não me conhece.

Dênis: Mas isto incomodava a senhora, Dona Maria? Como é que a senhora se sentia, assim... Porque... A senhora não fuma maconha?

Dona Maria: Ai guri, nem fala, credo em cruz! Tem uma venda aí que tirei o cheque pra ele... Eu comprava lá, né? Cheque de cinqüenta cruzeiro. Agora ele não quer me pagar. Ele tá na assistência social. Aquele dia que eu vim lá de cima, eu fui ali e disse que eu não sou maconheira, eu não sou sem vergonha, nem sou ladrona. Aí ele disse: "Ah, o que que tem, que tu tirou tudo.". "'Ó, sabe de uma coisa: vai toma no teus olho, vai tomar naquele lugar, vai pra puta que te pariu, (...) porque eu entro aí dentro e quebro tudo!”. Eu, quando era mais nova, tu me pega numas coisa que eu não gostava eu quebrava tudo.(...) Não era católica assim, e coisa.

\footnotetext{
11 - Afirmo esta diferença menos em face de conhecimentos teóricos sobre o assunto, mas muito mais em função de minha experiência empírica como trabalhador - já há cinco anos - em prevenção, recuperação e redução de danos relacionados ao uso indevido de drogas. O olhar que percebo nas senhoras do Morro da Cruz é muito mais próximo do que entendem os especialistas no assunto, do que o olhar de grupos ligados à classe média, em que pese seu maior grau de escolaridade e seu maior acesso à informação.
} 
Dona Maria demonstra naturalidade ao falar do marido como vendedor de maconha. Porém, ao nos contar a história da tentativa de desconto do cheque junto ao vizinho comerciante, deixa-no clara sua posição sobre o assunto: "eu não sou maconheira, eu não sou sem vergonha, nem sou ladrona". Deste modo, deixa claro que considera estas categorias - maconheiro, sem vergonha e ladrão - como próximas ou até mesmo inseparáveis. Porém, se estas categorias são inseparáveis, por outro lado elas não são necessariamente razão para que se evite o convívio com uma pessoa. Seu Chico, ao que tudo indica, era maconheiro, ladrão e sem vergonha, mas nem por isso merecia o desprezo de Dona Maria, até mesmo porque, a bem da verdade, ela "Não era católica assim, e coisa...".

Quando perguntada a respeito das ligações entre os assaltos ocorridos na Casa das Vós e o uso de drogas, o olhar de Dona Maria é este:

Dona Maria: Não é isso. É gurizada que quer levar pra casa, que a Dona Judite descobriu. Tira, rouba tudo, depois vende, tu entendeu como é?

Dênis: Mas não é pra comprar droga então?

Dona Maria: Não é pra comprar droga. O causo é esse. Eu vi ela te dizer que era, mas eu nem me colei naquilo. Imagina, eu tô sabendo... Eu e a Dona Judite era o mesmo que duas irmã. (...) A gente sentava ali, a gente ficava, tomando chimarrão. Aí ela: "Minha velha, é assim, assim, e assim...". E eu digo: "Ah, bom...". Ela dizia pra mim assim: "Tu viu só o que é que fizeram?". E o dia que levaram tudo. Tudo. Mas não era maconheiro. Não era. Era... Faziam assim: eles roubavam e vendiam, e a gente sabia onde é que eles vendiam. Vendiam aí pela redondeza.

Dona Cleusa, por seu turno, demonstra um pouco do que eu chamo de "olhar sofisticado", quando busca explicar as razões pelas quais os jovens de hoje agem de modo criminoso para com espaços comunitários que, no passado, eram respeitados, como a própria Casa das Vós, ou a creche, por exemplo:

Dênis: Dona Cleusa, então eu tenho que perguntar uma coisa pra senhora, que é uma das coisas que mais me interessa nesse trabalho que eu estou fazendo: A senhora acha que tem alguma diferença entre esta gurizada que usava droga naquele tempo, e a gurizada que usa droga hoje em dia?

Dona Cleusa: Pra mim, eu acho tudo a mesma coisa. Que eles praticamente mudar foi as pessoas que tão aqui, em comparação.

Dênis: Explica isso pra mim, por favor: 
Dona Cleusa: Tá: ali na creche tem uma coordenadora, tá? E ninguém gosta dela. No causo, parece assim que são... Parece uma criança, que tu fala uma coisa, e ela faz assim tipo uma birra, sabe? Se ela vai chamar atenção, conversar com eles, assim, depois eles faz uma maldade. Eles jogam sujeira pra lá... Eu sei porque, daí, quando eu tava ali, às vezes eu conversava (...) E eu dizia: "Ó gente: a creche ainda é a creche, no causo, dos filho de vocês, dum parente de vocês. Vocês não faziam isso aí de primeiro, gente". Já imaginou se eles fizesse aquilo ali? Que que era feito daquilo ali? Era tudo aberto. Eles tinham roubado até o telhado. Depois, quando foi mudando... O Padre Lauri, eles tinham uma raiva do Padre Lauri... Até eu ficava com vergonha. Até o carro dele eles tentaram de roubar. Então, sei lá: parece que eles não aceitaram. Ó, aqui ó: Tu tá vendo tudo isto aqui, né? (mostra os móveis dentro da Casa das Vós). Só qu e metade destas coisa aqui não ficava aqui também. É que a Márcia é conhecida. Se eles entram aqui e vêem que é ela eles mesmo dizem: "Ó, pode sair daí que...". A Márcia, esses dias tava me contando que ela ouviu um barulho aqui, aí ela entrou e viu um guri de lá de baixo que ela conhece, e daí diz que ela disse: "O que que tu tá fazendo aí?" Daí diz que ele - durinho, né? - diz que ele olhou e perguntou: "E a senhora, o que que tá fazendo aí?". Aí ela mostrou a chave assim. "Ah, mas vai dizer que e a senhora que tá cuidando aqui?". "Claro que é, né?".E o gu ri se mandou. Eles faziam as sacanagens dele, mas com quem era de fora. E se alguém fizesse alguma sacanagem com a gente, eles iam atrás e buscavam.

Dona Cleusa aponta para o fato de que a mudança de atitude dos usuários de drogas deve-se a uma represália em função do descontentamento com o modo como as políticas comunitárias vêm sendo tratadas pelo Instituto Murialdo. Diz que os jovens vêm sendo desprestigiados pelas coordenações de alguns dos espaços - principalmente a creche. Dona Márcia concorda, e conta que certa noite cedeu a Casa das Vós para que os jovens fizessem uma reunião (posteriormente, descobri que se tratava de uma reunião do movimento Hip Hop da comunidade):

\footnotetext{
Porque tu vê, aquela noite, se eu dissesse "Não, não vou deixar, vocês não podem entrar ali”, ele não ia poder fazer a reunião com a piazada, porque eles não tinham pra onde ir. E aí, até seria uma coisa que outros guri mesmo podiam ficar revoltados. Dizer "Pô, tem tanto espaço aqui, e a gente não pode usar". E pelo que eu entendo, é da comunidade. Quando foi feito, foi feito pra comunidade. (Dona Márcia)
}

Ler os eventuais atos violentos dos jovens da comunidade a partir desta ótica sofisticada não é de modo algum algo comum. Mesmo dentro da universidade, a maioria 
das pessoas ainda ligaria estes atos ao crescimento do consumo do crack, por exemplo, ligando eventuais assaltos à necessidade de manutenção da dependência. Mas estas senhoras "olham" para estes eventos como um texto, e sobre ele exercitam sua leitura. Procuram "ler o baralho".

Isto não quer dizer, no entanto, que tal leitura corresponda à realidade. Sabemos que uma leitura da realidade é apenas uma leitura da realidade, não podendo ser jamais confundida com a realidade em si. Mas, não precisamos comprovar a realidade de uma informação para que consideremos seu valor científico. Se há um texto sendo dito por um informante, será com este texto que iremos nos relacionar. Se Dona Cleusa acredita que os assaltos aos espaços do ILEM devem-se à indignação dos jovens diante das arbitrariedades cometidas pelos dirigentes do Instituto, será com esta visão que irei me relacionar. Mas, por outro lado, não posso deixar de pensar em outras declarações oferecidas, e que também podem contribuir para que a leitura desta senhora seja como é:

Eu sei que eu saí dali, não... Até inclusive eu falei assim: "Tá Padre, eu sei como é que a firma de hoje em dia, causa que... Quando eu entrei aqui eu era sã. Só que vai passando, pega minha idade, né?" Trabalhei doze anos ali. Onze de carteira assinada, e um ano de voluntária. Quando abriram a creche, eu entrei junto, só que eu entrei de voluntária. A Márcia disse: "Tu vai me ajudar?", e eu disse: "Vou". "Então vamos". Daí depois que a Dona Judite saiu eu fiquei no lugar da Dona Judite. Daí que eu fiquei de funcionária. Aí ele vai e me diz aquilo, né? Daí eu disse: "Padre, eu sei que as firma aceita as pessoa quando tão são mesmo. Quando fica doente, rua, esquece." "É que não dá mesmo... A senhora tá doente, e nós não queremo gente doente! A Mitra não aceita gente doente. $\mathrm{O}$ que a gente pede... A senhora cai fora, vai fazer um tratamento." Eu disse: "Tá." Só que... Aquele dizer dele ali... Bah! Tá louco! Essa gente pisa. Essa gente aí do Murialdo, eles pisam muito na gente. Eles falam bonito, mas eles não fazem a prática que eles falam. Não fazem mesmo. Não fazem. Tinham que pelo menos reconhecer as pessoas que lutam mesmo, de verdade. Hoje em dia eles não enxergam a gente. Facilita eles tropeçam na gente, eles pisam na gente. Eu tenho certeza que se pegar uma doença de... Mas... Quem é que vai lembrar que nós existe. Pelo menos rezar uma missa, um terço, uma coisa pra gente melhorar. A gente não é mais enxergado; a gente é enxergado enquanto tá trabalhando, deixando o couro ali. (Dona Cleusa)

Também não estou querendo dizer que toda a leitura de Dona Cleusa seja decorrente do fato de que ela sentiu-se desprezada pelos dirigentes do ILEM, e que em 
decorrência disto tenha se esforçado para me dizer que todos os problemas no Morro são uma decorrência dos problemas éticos dos padres do instituto. Não é isto. Mas, ao mesmo tempo, devemos observar todo o quadro antes de tirarmos conclusões precipitadas. Seria muito confortável. Mas a realidade não é assim tão confortável, e sua leitura nunca é tão simples.

\subsection{As Relações}

É claro que estes tópicos - olhar, histórias e relações - são absolutamente inseparáveis. Utilizei esta metodologia, a bem da verdade, apenas para evitar maiores confusões. Neste ponto, é possível que algumas das falas vistas anteriormente se repitam, para que possamos exercitar outros modos de interpretação dos textos apresentados por minhas informantes. Até porque estas senhoras não se limitam a contar histórias ou a apenas olhar para os usuários e vendedores de drogas da comunidade: elas interagem, convivem, dividem e trocam. Existem, portanto, relações diretas de convívio.

\footnotetext{
Eles prenderam porque ele tava junto com o outro que tinha - Bá! - tinha um ficha boa, desde pequeninho, né? Aí como ele tava junto - inclusive eles não tavam os dois juntos, porque o outro tinha entrado no ônibus, ele já tava assim, né? E o Beto, como já tava bem chapado - quando ele se chapava ele tinha a mania de sentar ou de andar devagar - sentou e ficou. Mas como eles viu que os dois entraram juntos, eles acharam que eles: "Ó, esse aqui é acostumado a assaltar ônibus; aquele lá tá junto, tá olhando" - né? Qualquer coisa assim... Daí foi onde que levaram. Aí ele ficou. Daí eu fui lá, visitei ele, tudo, inclusive ele nem queria que eu fosse. "Não, mas eu vou, né?". Fazer o quê? Não era roubo, não era, digamos assim: tem coisa que marca muito né? (Dona Cleusa)
}

Novamente, Dona Cleusa nos demonstra que a noção de que há uma deterioração nos sentimentos de maternidade por parte das populações de periferia não encontra uma unanimidade no mundo real, para além do discurso. É claro que talvez isto de deva ao fato de que grande parte da população do Morro da Cruz é oriunda de cidades do interior, e um ethos comunitário e urbano ainda está em formação. Estamos falando de uma comunidade que começou a ser ocupada há pouco mais de cinqüenta anos. Das senhoras que fazem parte do grupo das Caminheiras da Paz, poucas vivem na comunidade há mais de vinte e 
cinco anos. Porém, este dado aumenta ainda mais a perplexidade com que observamos o modo como estas senhoras convivem com o mundo da droga.

Bom... A única coisa que eu fiz, daí, essa minha comadre: "Ó; pega as criança, pega - eu tinha a minha guria mais velha só - pega e vai pra baixo da cama". Então foi o que eu fiz, né? Fui pra baixo da cama. Daí era tiroteio entre eles. Daí... Eles Depois... Daí eu fui me acostumando aos poucos, né? Eu precisava de morar aqui, não tinha outro lugar pra ir. Claro que no começo foi brabo, mas esta minha comadre, ela foi muito boa pra mim, boa mesmo, assim ó: não tenho queixa. Devo obrigação pra ela. Daí era aquilo né... Eles... Em quantas vezes inclusive este Beto, filho do finado Carioca, ele, hã, deram oito balaço nele uma vez. Daí a polícia tava de atrás dele, ele ficou escondido nos capim de elefante ali. O meu marido toda noite chegava, ia lá, fazia curativo, aplicou injeção nele. (Dona Márcia)

A solidariedade aparece com força. No livro de Cláudia Fonseca, estes relatos aparecem com grande profusão (Fonseca, 2000). De nossa parte, não desejamos de modo algum questionar este sentimento solidário que parece ser um ponto central nas relações de vizinhança em comunidades populares. Mas, a bem da verdade, talvez seja também interessante levar em consideração o fato de que existem outros fatores envolvidos nesta história. Quero crer que o marido de Dona Márcia cuidaria de um homem necessitado de qualquer forma. Mas, seria interessante não esquecermos de que, logo no primeiro dia em que esta família chegou ao Morro da Cruz, o aviso foi de que tudo estaria bem caso ninguém visse nada. O pedido - que me soa como uma orientação ao respeito pelas regras da comunidade, e não uma ameaça - inclui algo mais do que apenas um convite à cegueira; inclui um convite à solidariedade. Deste modo, cuidar de um homem baleado é o mínimo que se pode esperar de um vizinho.

Dona Maria: Agora que a polícia não tem vindo. Mas teve uma época que tu não sabia quem era os maconheiro, de tanto que tinha. Teve uma época que tu descia ali, e só tinha maconheiro. Agora não, porque a policia bate. Bateu domingo, sabe? Lá pra, cima, lá pros lado da igreja, sabe? Mas tu tem que vim aqui num sábado, assim.

Dênis: Tipo que horas, assim? É de dia ou de noite?

Dona Maria: De dia! De tarde. Vem num dia que tenha folgado. Vem aqui que eu te levo lá em cima.

Dênis: Mas a senhora fala o que? É maconha?

Dona Maria: Eu não sei! Cheiro, maconha, não sei. O Marinho cheira aquela cola lá, não sei. A mãe dele fica brava... 
Dona Maria relata sua proximidade com a droga ainda hoje, mesmo depois da morte de Seu Chico. Marinho, o jovem de quem ela fala, é meu conhecido do tempo em que fui educador do Serviço Civil Voluntário. Assumidamente um usuário de drogas, Marinho é um jovem por quem todos nutrem afeto, devido ao modo debochado com que se porta. Ao final de uma entrevista, saí com Dona Maria para que juntos fôssemos à casa de uma vizinha. No caminho, encontramos Marinho, e eu fiquei realmente impressionado com o respeito devotado por ele a esta velha senhora. Não que Marinho seja um jovem desrespeitoso, não é isto; mas ele tem este jeito debochado e brincalhão que alguns jovens têm, e que talvez seja típico dos dias de hoje. Pois me impressionou a forma absolutamente respeitosa, solene mesmo, com este jovem comportou-se diante de Dona Maria, que por seu turno, pediu educadamente algumas informações sobre a mãe do jovem. Marinho perguntou-me o que fazíamos juntos, e me pareceu ter ficado mais tranqüilo quando disse que se tratava de uma entrevista para um trabalho da faculdade.

Não sei se Marinho tratou Dona Maria daquele modo pelo fato de eu me fazer presente. De qualquer modo, uma coisa fica clara: existem relações entre estes jovens e estas senhoras, e não há, nem de uma parte, nem de outra, um desejo de distanciamento, muito comum em rodas de usuários de drogas em outras regiões da cidade.

\subsection{Os Mitos}

$\mathrm{Na}$ entrevista que fiz com Dona Márcia, o assunto girou durante um bom tempo em torno da figura de Carioca. Sucessor de Anão na liderança do tráfico no Morro da Cruz, este ruivo franzino acabou por tornar-se um verdadeiro mito, não apenas na localidade onde imperou como líder marginal, mas na cidade como um todo. Cláudia Fonseca, que realizava sua pesquisa no Morro da Cruz justamente na época em que Carioca "foi suicidado", descreve assim seu enterro:

Às cinco hora da tarde, as quase mil pessoas presentes ao velório saíram para seguir o corpo de Carioca até o cemitério. O cortejo funerário seguiu morro abaixo até a rua onde Carioca tinha morado na Vila Vargas, zona que costumava chamar de "Coréia". Como de costume entre policiais e militares mortos em serviço, "os soldados" saudavam seu chefe com salvas de tiros. 
Nesse caso, os soldados eram homens fora-da-lei escondidos no mato que circundava o bairro. (Fonseca, 2000)

Dizem-se coisas fantásticas sobre Carioca, e também sobre Anão. No entanto, vamos no fixar unicamente na figura de Carioca, devido à sua maior proximidade com o tempo do qual olhamos para o passado. Um pouco antes da descrição dos funerais, Fonseca conta que durante sua viagem de táxi até o morro, em algum momento ela solicita ao motorista que ligue o rádio, pois deseja mais informações sobre Carioca. O motorista, então, fica sabendo do ocorrido. A chegarem ao local do velório, o motorista desceu do carro junto com a antropóloga, para prestar ele também uma última homenagem ao heróibandido, como aconteceu com João de Santo Cristo (Faroeste Caboclo, 1987).

Herói-bandido. Talvez seja justamente este o arquétipo representado por Carioca. Inúmeras lendas e mitos foram construídos ao longo da história, por inúmeros povos diferentes, envolvendo a figura de um herói fora da lei, adorado por seu povo (Campbell, 1990). No Morro da Cruz, tal herói se justifica ainda hoje:

\footnotetext{
Dona Márcia: Eu acho que as pessoas que moram aí - que eu digo "ladrão chinelo", né? - não tem respeito pela gente. O que falta aqui, eu acho assim - porque polícia não adianta. Tu chama a polícia eles não fazem nada. Precisava era mesmo de um "patrão" que nem tinha antes, que dizia, que botasse respeito aqui nessa chinelagem... Porque se te roubam, tu chama a polícia, tu vai lá e a polícia diz que não pode fazer nada. A única coisa que eles querem é nota. Tu compra uma televisão usada lá, eles não te dão nota. Aí tu vai lá, eles... A primeira coisa que eles querem é nota. Uma vez me roubaram minha televisão, minhas coisa de dentro de casa, ali. Fui lá na polícia, fiquei uns dois dia esperando, não apareceram. Aí peguei meu sobrinho: ele pegou um revólver, mesmo... Nós mesmo fomo buscar.

Dênis: E buscaram?

Dona Márcia: Claro! Porque a polícia... Então, eu acho assim: $\mathrm{Eu}$, todos os anos que eu moro aqui no morro, o que precisava mesmo era de um "patrão"; uma pessoa que botasse respeito aí...
}

Carioca não era um "ladrão chinelo". Aliás, no seu tempo, "ladrão chinelo não se criava". A noção de que um "patrão" resolveria os problemas do morro é extremamente forte. Na verdade, quando confrontadas a possibilidade de surgimento de um "patrão forte" com a opção de uma presença mais ativa da polícia, a posição destas senhoras dá conta de que seria mais seguro e eficiente contar com um patrão, e quando se pede uma explicação, 
temos referências um tanto quanto vagas. O que fica sempre muito claro é a defesa da honestidade de Carioca diante de desonestidade da polícia:

\begin{abstract}
A fonte ilegal da riqueza destes líderes não chegava a ser um problema. $\mathrm{O}$ que eles faziam não era visto como particularmente repreensível. "Não eram bandidos". Ao falar deles, os moradores da vila costumam dar uma série de explicações para abrandar o lado sombrio de suas atividades. ("Não é ladrão, é traficante, e disso tem muitos por ấ". "Não é um marginal. Só rouba de banco e não faz mal a ninguém". "O verdadeiro bandido é aquele que tira dinheiro do bolso do operário".) Sublinha-se constantemente o fato de que Carioca não usava a violência. (Fonseca, 2000)
\end{abstract}

Enquanto estive envolvido com a pesquisa, tive a oportunidade de assistir a três filmes sobre Lampião. O primeiro mostrava o cangaceiro (o nome de Lampião não era utilizado, apesar das claras referências) como uma figura perversa, que ordena o estupro e morte da esposa do "mocinho", que acabara de casar-se. Infelizmente não guardei as referências deste filme. O segundo traz a figura de Lampião como bandido, enfrentado pelo “mocinho", que é interpretado pelo impagável Alberto Ruschel (O Cangaceiro, 1953). Por fim o terceiro traz um Lampião romantizado, afeito aos perfumes e às negociações políticas, utilizando a violência contra os "macacos" (policiais), que tomam o posto de vilões na trama (O Baile Perfumado, 1997).

Assistir a estes filmes trouxe-me alguns insights sobre o mito do herói-bandido. No caso de Lampião, estes três filmes puderam mostrar como foi a evolução do olhar sobre o cangaceiro Virgulino Ferreira ao longo de cinqüenta anos. O primeiro, cujo nome não lembro, e que era certamente mais antigo que o segundo, dá conta de uma determinada visão, extremamente maniqueísta - provavelmente reputada ao fato de que o filme é feito ainda sob o manto da Ditadura Vargas. O segundo já demonstra uma evolução, em todos os níveis, tendo levado a Palma de Ouro em Cannes como o melhor filme de ação, já que naquele tempo as premiações eram divididas por categorias. Fosse em outro tempo, e talvez o filme de Lima Barreto tivesse levado o prêmio de melhor filme.

Mas não é isto que nos importa. O fato é que "O Cangaceiro" apesar de ainda situar Lampião no lugar do bandido, já rompe com uma certa forma de manipular o vilão, abrindo espaço para um novo olhar. Porém, será somente a partir de Glauber Rocha que esta visão do cangaceiro como herói vai tomar conta das telas. Em "O Baile Perfumado", 
terceiro filme da lista que apresentei, tal concepção toma finalmente os contornos sobre os quais desejo falar. Este filme de 1997 tem sua trama centrada na figura de Benjamin Abrahão, mostrado aqui como uma espécie de antropólogo, que foi a única pessoa a conseguir filmar Lampião. Neste filme, o Rei do Cangaço é demonstrado como uma figura enérgica, capaz de atos violentos, extremamente justo e inimigo dos "macacos" (policiais).

A bem da verdade, eu já havia assistido ao filme de Lima Barreto vários anos antes, e quanto ao Baile Perfumado, havia assistido em 2003. Porém, revê-los através do Canal Brasil na ordem que descrevi foi extremamente interessante para que eu pudesse compreender um pouco o processo de formação do mito de Lampião em nível nacional. Olhando deste modo, temos os contornos desejados para uma abordagem ligando a figura mítica de Lampião ao herói-bandido do Morro da Cruz, Carioca.

"O Baile Perfumado" mostra um Lampião capaz de receber um misto de jornalista-cineasta-antropólogo, e com este construir um canal de negociação e de diálogo. Do mesmo modo, todos os relatos dão conta de que Carioca era extremamente receptivo aos contatos da mídia, pois entendia a importância da construção de uma imagem perante a opinião pública. Em outro ponto da fita, Lampião aparece jogando cartas com o Coronel João Libório, enquanto conversa sobre aspectos da política regional (essencialmente coronelista). Igualmente, Carioca dialogava com as lideranças da comunidade, comportando-se ele também como um líder de um determinado segmento. Por fim, Lampião aparece, em vários momentos, demonstrando sua fé religiosa. Quanto a isto, não possuímos relatos, mas o fato é que Carioca relacionava-se abertamente com as lideranças católicas da comunidade, e mais especialmente com o Padre Ângelo, este também uma figura mítica para os moradores do Morro da Cruz.

Existem outros personagens míticos - literários ou reais - com os quais podemos estabelecer relações: Zorro, por exemplo, que enfrenta a lei no sentido de proteger sua comunidade da violência do braço armado do Estado (ainda que boa parte desta violência seja amplificada por suas ações). Robin Hood não poderia ser deixado de lado: a imagem do mal-feitor que se torna bem-feitor, e que no jargão clássico, "Rouba dos ricos para dar aos pobres", é clássica demais para ser desprezada. Mas para tornar esta análise um pouco mais sofisticada, vamos nos valer de um outro personagem mítico, muito mais próximo de nossa história regional, porém muito mais desconhecido. 
Herói-bandido clássico, se é que se pode dizer isto, o imigrante italiano Campara centrou suas ações próximo à região do Rio Grande do Sul (Fagundes, 1996). Com uma semelhança impressionante ao modelo de ação demonstrado nos filmes de Robin Hood (Robin Hood - O Príncipe dos Ladrões, 1991), Campara roubava mercadores e outros viajantes que ousavam atravessar seu território, durante a segunda metade do século XIX. Segundo todos os relatos históricos, ele realmente roubava apenas dos ricos, dividindo uma parte do butim com os menos favorecidos.

Campara acabou sendo preso, e durante sua prisão em Porto Alegre, ficou sob os cuidados de um personagem não menos famoso - um homem chamado José Ramos, mas que entrou para a história como o "Lingüiceiro da Rua do Arvoredo". José Ramos era carcereiro, e tentou matar Campara enquanto este estava sob seus cuidados. O Historiador Décio Freitas traz luz ao encontro entre Campara e José Ramos, mas não esclarece os motivos que lavaram o carcereiro a tentar matar a herói-bandido (Freitas, 2002). Não deixa de ser curioso que dois personagens tão especiais de nossa história tenham se cruzado. Só faltou uma improvável Jacobina Maurer de passagem por Porto Alegre, porque não, de braços com um Qorpo Santo.

Campara, portanto, oferece um arcabouço estético e ético completo para que se possa fazer algumas comparações com Carioca. Assim como o primeiro, o segundo era também fora-da-lei, bondoso para com seus pares, tirando dinheiro apenas dos ricos, já que suas duas atividades marginais - comércio de drogas e roubo de bancos - no olhar dos moradores do Morro da Cruz, constituem-se em "roubar dos ricos". Carioca, assim como Campara, também possui um território específico, entendido aqui como uma porção da superfície terrestre definida pela ação de um determinado grupo, e não por suas características de relevo, clima ou hidrografia.

Voltando a falar de filmes, mas já preparando uma transição, podemos trabalhar ainda com outro mito eternizado pelo cinema brasileiro: Tenório Cavalcanti (O Homem da Capa Preta, 1986). Trazer a figura de Tenório a este trabalho joga luz em uma outra característica importante, não só de Carioca, mas dos traficantes de um modo geral: o estabelecimento de relações de patronagem/clientelismo (Grynszpan, 1990). Não à toa, o termo utilizado para designar o chefe do tráfico em um determinado território é justamente 
"Patrão". Como diz Dona Márcia: "Eu, todos os anos que eu moro aqui no morro, o que precisava mesmo era de um patrão; uma pessoa que botasse respeito aí...".

Um patrão "bota respeito"; estabelece limites à ação dos outros marginais, colaborando para a construção de um conjunto de normas tácitas em meio ao desvio. Mas, é importante que se diga: sua força não nasce de uma atitude violenta. Ele domina este código, mas a violência deve permanecer, ao máximo possível, na forma de potência, e não em ato constante. O que vai diferenciar um patrão de um mero fora-da-lei é justamente sua dimensão mítica, que se constrói ao longo do tempo, e sua presença - física ou moral mantém a ordem estabelecida (mesmo quando Carioca estava na cadeia, sua "presença" mantinha a ordem no Morro da Cruz). Outro detalhe importante que nos permite considerar Carioca como um patrão (compreendido aqui como categoria sociológica), é o fato de que a comunidade estabelecia com ele relações diretas e hierarquizadas. Quando alguém precisava de algo - remédios, comida, dinheiro ou proteção - era a carioca que se devia procurar. Não ao Estado; não ao posto de saúde; não aos comerciantes; não à polícia: ao Carioca.

Infelizmente, não tive tempo de colher mais informações e relatos que pudessem ser utilizados para uma investigação mais aprofundada a respeito da importância deste mito na comunidade. Guardada a possibilidade de que todas estas conjecturas acerca da existência de um mito em torno de Carioca não passam de suspeitas, o fato é que sua lembrança ainda é extremamente viva nesta comunidade, até mesmo por quem não viveu seu tempo. Se, de um lado, vemos que as senhoras se ressentem da falta de um Patrão, por outro lado, ser um Patrão como Carioca habita os sonhos de muitos os jovens moradores desta comunidade.

Para encerrar, reproduzo aqui trechos de uma conversa que não presenciei, mas que me foi repassada por minha amiga Nice. Estava ela reunida com seu grupo de senhoras na Casa das Vós, conversando sobre um recente furto ocorrido na creche. Nice conta que, em determinado momento, uma das senhoras, sem levantar os olhos da tapeçaria na qual trabalhava, disse, em voz lenta e baixa, quase solene:

No tempo do Carioca não tinha essas coisas... 
Mais nada. Apenas isso: "No tempo do carioca não tinha essas coisas...". Num ato reflexivo, numa fala quase silenciosa, numa reminiscência. Após a fala da senhora, conta Nice, houve alguns breves instantes de silêncio recheado de cumplicidade. Uma fala, enfim, plena de significados.

Quase como uma oração.

\section{5. "Fazendo Fuxico"}

Uma das atividades comuns aos encontros das Caminheiras da Paz na Casa das Vós é a produção de fuxicos. O fuxico é um tipo de trabalho com linhas trançadas com agulhas de crochê, que resulta em pequenos patchs que podem ser utilizados na confecção de uma infinidade de produtos: colchas, corpetes, vestidos, toalhas (uma vez, na oficina de produção da Grife Morro da Cruz, tive a chance de ver um vestido de noiva feito totalmente de fuxicos, a venda por uma ninharia). Por ser uma atividade tradicionalmente coletiva, e que via de regra reúne grupos de senhoras, "fazer fuxico" acabou por tornar-se sinônimo de fofocar, conversar, trocar idéias. Por ser uma atividade que exige concentração, as conversas durante o fuxico são feitas em voz baixa, sem que a artista tire os olhos do trabalho.

A utilização deste título para este capítulo tem duas razões: primeiro, por óbvio, aproveitar a chance para descrever mais uma característica do grupo; segundo, para tentar conservar este espírito reflexivo com o qual as conversas fluem durante o ato de "fazer fuxico". Inicialmente, pensei em chamar este capítulo de "Sentando e Olhando", expressão que eu havia retirado de um livro do Lama Padma Santem, mestre do buddhismo tibetano e ex-professor do Departamento de Física da Universidade Federal do Rio Grande do Sul, à época, com o nome de Alfredo Aveline. O espírito ainda é o mesmo: sentando e olhando, buscando a lucidez.

Fazendo, portanto, meu fuxico solitário, converso em tom reflexivo comigo mesmo, tentando entender um pouco mais do que aconteceu durante este processo de introdução à pesquisa. Aceitei o desafio de levar realmente a sério esta atividade, e em poucos momentos optei pelo caminho mais fácil no decorrer do processo. Um destes momentos foi na elaboração da contextualização, onde me dei conta de que um trabalho 
como eu realmente gostaria de ter feito tomaria provavelmente todo o tempo que eu tinha disponível em pesquisas bibliográficas. Principalmente no caso da contextualização do tema "Droga", optei conscientemente por um caminho de redução de potencialidade, para evitar o risco de que este acabasse se tornando um trabalho sobre a história das drogas. Até mesmo porque, fosse este o objetivo, mais fácil seria embalar os três volumes da obra de Escohotado e entregar à professora (Escohotado, 1995).

Outro momento em que optei por um caminho mais fácil foi justamente onde eu mais devia ter me empenhado: o trabalho de campo. A opção por restringir o número de entrevistas não me parece ter sido equivocada em si, mas percebo que deveria ter buscado um número um pouco superior ao qual acabei me fixando; talvez cinco (e não três), fosse um número bom. Porém, o mais sério não é isto, pois até mesmo com três entrevistas, eu poderia ter feito um trabalho superior. O fato é que percebo que acabei me retirando do campo cedo demais. Acabei empolgando-me com o processo de objetivação, deixando o trabalho de campo em segundo plano, e acomodando-me com um número extremamente baixo de entrevistas e visitas às minhas senhoras, o que acabou restringindo também meu material de pesquisa, meus subsídios.

Por exemplo: tenho certeza absoluta de que eu poderia colher uma quantidade muito maior de depoimentos sobre a formação de um mito acerca da figura de Carioca. Tais declarações talvez confirmassem, talvez derrubassem minhas suspeitas. Não importa. O que importa é que eu acabei ficando com apenas uma única declaração sobre o assunto, o que é obviamente muito pouco. Não obstante, este tema pareceu-me tão importante, que mesmo com base em apenas uma declaração, construí um conjunto de argumentos, e busquei tecer uma série de hipótese a respeito. Decididamente, isto não parece lá muito científico...

Relaxando um pouco nas exigências pessoais, e reconhecendo que o objetivo deste trabalho não era outro senão aproximarmo-nos do mundo dos estudos de antropologia social, reconheço que fui picado. Assumo que estou irremediavelmente contaminado pelo vírus da antropologia. Pude perceber, na prática, o potencial desta disciplina. Fiquei imaginando onde poderia ter chegado este meu estudo, se houvesse para tanto mais tempo (uns dois ou três anos), e o auxílio luxuoso de um orientador mais próximo. Eis aí uma experiência pela qual não abro mão de passar. 


\section{REFERÊNCIAS}

BARRETO, Frederico Flósculo Pinheiro. Espaços para a Terceira Idade. Revista Humanidades. Brasília: Editora da UNB, n. 46, Out. 1999. p. 54 - 65.

BERRIDGE, Virginia. "Dependência: História dos Conceitos e Teorias". In: EDWARDS, Griffith \& LADER, Malcolm. A natureza da dependência de drogas. Porto Alegre: Artes Médicas, 1994.

BLIXEN, Samuel. O negócio da droga, sócio do neoliberalismo. Porém - Cultura \& Política. Porto Alegre: n. 3, jul./ago. 2003. p. 31 - 33.

BRASIL, Ministério da Saúde. A Política do Ministério da Saúde para a Atenção Integral a Usuários de Álcool e outras Drogas. Brasília, 2003.

CAMPBELL, Joseph. O Poder do mito. São Paulo: Palas Athenas, 1990.

CENTRO DE ASSESSORIA MULTIPROFISSIONAL. Morro da Cruz-Lugar bom de se morar. Porto Alegre: CAMP, 1993.

CONTE, Marta. A clínica psicanalítica com toxicômanos: O "Corte \& costura" no enquadre institucional. Santa Cruz do Sul: Editora da Universidade de Santa Cruz do Sul, 2004.

ESCOHOTADO, Antonio. Historia general de las drogas 1. Madrid: Alianza Editorial, 1995.

ESCOHOTADO, Antonio. Historia general de las drogas 2. Madrid: Alianza Editorial, 1995.

ESCOHOTADO, Antonio. Historia general de las drogas 3. Madrid: Alianza Editorial, 1995.

FAGUNDES, Antônio Augusto. Mitos e Lendas do Rio Grande do Sul. Porto Alegre: Martins Livreiro Editor, 1996.

FILHO, Durval Mazzei Nogueira. Toxicomanias. São Paulo: Editora Escuta, 1999.

FONSECA, Cláudia. Família, fofoca e honra: etnografia de relações de gênero e violência em grupos populares. Porto Alegre: Editora Universidade/UFRGS, 2000. p. 89-208.

FOOT-WHYTE, William. Treinando a Observação Participante. In.: GUIMARÃES, Alba Zaluar. Desvendando Máscaras Sociais. Rio de Janeiro: Editora Francisco Alves, 1990. p. $77-86$.

FOUCAULT, Michel. História da Loucura na Idade Clássica. São Paulo: Editora Perspectiva, 2004.

FREITAS, Décio. O maior crime da terra: o açougue humano da Rua do Arvoredo. Porto Alegre: Editora Sulina, 2002.

GASPAR, Maria Dulce. Garotas de Programa: Prostituição em Copacabana e Identidade Social. Rio de Janeiro: Jorge Zahar Editor, 1985.

GEERTZ, Clifford. A Interpretação das Culturas. Rio de Janeiro: LTC Editora, 1989.

GOFFMAN, Erwing. Estigma: notas sobre a manipulação da identidade deteriorada. Rio de Janeiro: LTC Editora, 1988.

GREGIS, Cristiano. Fissura de rua: Corpo e ritual de droga injetável entre meninos de rua. 80 f. Dissertação (Mestrado em Antropologia Social) - Programa de Pós-Graduação em Antropologia Social, IFCH, UFRGS, Porto Alegre 2002.

GRYNSZPAN, Mario. Os Idiomas da Patronagem: Um Estudo da Trajetoria de Tenorio Cavalcanti. Revista Brasileira de Ciências Sociais. São Paulo: ANPOCS/Vértice, n. 14, 1990. p. $73-90$. 
HENEMAN, Anthony Richard. "A Guerra às drogas é uma guerra etnocida: Um estudo do uso da maconha entre os índios Tenetehara do Maranhão”. In: ZALUAR, Alba (org.). Drogas e Cidadania: repressão ou redução de riscos. São Paulo: Brasiliense, 1994. p. 47 81.

KALINA, Eduardo. Drogadição hoje: Indivíduo, família e sociedade. Porto Alegre: Editora Artes Médicas, 1999.

LOUREIRO, Altair Macedo Lahud. Velhice: encantos, desencantos... reencantos. Revista Humanidades. Brasília: Editora da UNB, n. 46, Out. 1999. p. 77 - 86.

MACRAE, Edward. A Abordagem Etnográfica do Uso de Drogas. In: ZALUAR, Alba (org.). Drogas e Cidadania: repressão ou redução de riscos. São Paulo: Brasiliense, 1994. p. 99 - 114.

MORAES, Marcelo Estevão de. Seguridade Social e Direitos Humanos. Trabalho apresentado no "Seminário Desafios da Previdência: atualidade do pensamento de Francisco Oliveira". Brasília: Instituto de Pesquisa Econômica Aplicada, 2002. Disponível em < http://www.ipea.gov.br/TemasEspeciais/previdencia.htm>. Acessado em <10/06/04>. MORETZSOHN, Sylvia, et alli. "Todo crime é político": Entrevista com Nilo Baptista. Caros Amigos. São Paulo: Ano VII, n.77, Ago. 2003. p. 28 - 33.

MORIN, Edgar. Introdução ao Pensamento Complexo. Lisboa: Editora Instituto Piaget, 1991.

NUNES, Márcia Batista Gil; MAURO, Cileia do Nascimento Silva Ramos \& CHAVES, Maria Yvone. Estudo das políticas de proteção as pessoas da terceira idade no Brasil - 2003. Disponível em $<$ http://www.direitodoidoso.com.br/01/artigo011.html>. Acessado em <12/06/2004>.

PAIXÃO, Antônio Luiz. "Problemas sociais, políticas públicas: o caso do tóxico". In: ZALUAR, Alba (org.). Drogas e Cidadania: repressão ou redução de riscos. São Paulo: Brasiliense, 1994. p. $129-145$.

PESSOTTI, Isaias. Os Nomes da Loucura. São Paulo: Editora 34, 1999.

PICCOLO, Fernanda Delvalhas. "Particularidades e generalizações: reflexões a partir de uma pesquisa urbana entre usuários de drogas em Porto Alegre”. In: VELHO, Gilberto \& KUSCHNIR, Karina. Pesquisas Urbanas: Desafios do trabalho antropológico. Rio de Janeiro: Jorge Zahar Editor, 2003. p. 55 - 68.

PICCOLO, Fernanda Delvalhas. "Se deixar a droga levar..." Um estudo sobre as trajetórias sociais de usuários de drogas injetáveis em uma vila de Porto Alegre. $119 \mathrm{f}$. Dissertação (Mestrado em Antropologia Social) - Programa de Pós-Graduação em Antropologia Social, IFCH, UFRGS, Porto Alegre, 2001.

RAMOS, Paulo Roberto Barbosa. O Estatuto do Idoso - Primeiras Notas para um Debate - 2004. Disponível em <http://www.direitodoidoso.com.br/01/artigo021.html>. Acessado em $<10 / 06 / 2004>$.

SANTANA, Adalberto. A Globalização do narcotráfico. Revista Brasileira de Política Internacional. Ano 42, no 2. Instituto Brasileiro de Relações Internacionais. Brasília, 1999.

SHIRLEY, Robert W. Atitudes com relação à polícia em uma favela do Rio Grande do Sul. In: RIO GRANDE DO SUL. Secretaria de Justiça e Segurança. Curso de Ações Básicas de Segurança Pública: Uso da Força e da Arma de Fogo. Porto Alegre: 2001. p. 11 - 19.

SOUZA, Aline Iara de. Estratégias de saúde e qualidade de vida em uma vila popular do município de Porto Alegre. 97 f. Dissertação (Mestrado em Enfermagem) - Programa de Pós-Graduação em Enfermagem, Escola de Enfermagem, UFRGS, Porto Alegre, 2002. 
SOUZA, Elza Maria de. As Lembranças como Patrimônio Social. Revista Humanidades. Brasília: Editora da UNB, n. 46, Out. 1999. p. 103 - 108.

VELHO, Gilberto. Nobres \& Anjos: um estudo de tóxicos e hierarquia. Rio de Janeiro: Editora Fundação Getúlio Vargas, 1998.

VELHO, Gilberto. “A dimensão cultural e política dos mundos das drogas". In: ZALUAR, Alba (org.). Drogas e Cidadania: repressão ou redução de riscos. São Paulo: Brasiliense, 1994. p. $23-29$.

ZALUAR, Alba. "A criminalização das drogas e o reencantamento do mal". In: ZALUAR, Alba (org.). Drogas e Cidadania: repressão ou redução de riscos. São Paulo: Brasiliense, 1994. p. 97 - 127.

ZOJA, Luigi. Nascer não basta. São Paulo: Editora Axis Mundi, 1992.

\subsection{Referências Cinematográficas}

O Cangaceiro. Direção: BARRETO, Lima. Companhia Cinematográfica Vera Cruz \& Columbia Pictures, 1953

O Baile Perfumado. Direção: CALDAS, Paulo \& FERREIRA, Lírio. Riofilme, 1997.

A Ópera do Malandro. Direção: GUERRA, Ruy. Austra Cinema e comunicações, MK2 Productions e TF1 Films Productions, 1985.

O Homem da Capa Preta. Direção: REZENDE, Sérgio. Morena Filmes \& Embrafilme, 1986.

Robin Hood - O Príncipe dos Ladrões. Direção: REYNOLDS, Kevin. Warner Bros / Morgan Creek Productions / TriStar Pictures, 1991.

\section{Referências Musicais}

CÉZAR, Chico. Béradêro. In.: Chico Cezar - “Aos Vivos”. Velas, 1995.

RUSSO, Renato. Faroeste Caboclo. In.: Legião Urbana - "Que país é este?”. Emi Odeon, 1997. 